\title{
Industrial Production and Capacity Utilization: Historical Revision and Recent Developments
}

Carol Corrado, Charles Gilbert, and Richard Raddock, of the Board's Division of Research and Statistics, prepared this article. Carly Kudon provided research assistance.

The Board of Governors of the Federal Reserve System has completed a revision of its measures of output, capacity, and capacity utilization for the industrial sector. The primary feature of the revision is a new formulation for aggregating the indexes and utilization rates using weights that are updated annually rather than every five years. The new formulation has been used to revise the output, capacity, and utilization rates back to 1977 . It provides more accurate current estimates of developments in industrial production and capacity utilization and eliminates an earlier, small overstatement of the growth trends of production and capacity.

For 1992 and thereafter, the 264 individual industrial production (IP) series also incorporate additional or updated statistics that are typically available for an annual revision. Moreover, we added or altered eleven production series to improve their market classification, coverage, and reliability; some of these improvements were made to pre-1992 figures, depending on the availability of source data.

The industrial capacity indexes were reestimated from 1977 onward to be consistent with the revised IP series and updated measures of manufacturers' capital input. The revisions to both production and capacity indexes are, of course, reflected in the utilization ratio. Some additional small changes to aggregate capacity utilization rates were made from 1976 back to 1967 to improve their consistency with the new formulation.

Besides the reformulation of aggregates, the annual updating of all measures, and the improvement of selected series, the revised production and capacity indexes are now expressed as percentages of output in 1992. This rebasing affects all series from their

Note. Other contributors to the revision and to this article include the following: Ana Aizcorbe, William Cleveland, Christopher Furgiuele, Michael Mohr, Cora Moyers, Gerald Storch, and Dixon Tranum. start date, which is 1919 for total IP, 1948 for manufacturing capacity, and 1967 for total industrial capacity. The Federal Reserve's accompanying statistics for industrial electric power use, which begin in 1972, have also been rebased and revised to incorporate previously unavailable data.

\section{REVISIONS TO OUTPUT, CAPACITY, AND UTILIZATION}

The revised indexes of industrial production and capacity show slower growth, on average, than the earlier estimates, whereas the cyclical patterns of the revised measures are nearly the same as before (chart 1). Both from 1977 to 1987 and from 1987 to

1. Industrial production, capacity, and utilization, 1967-96

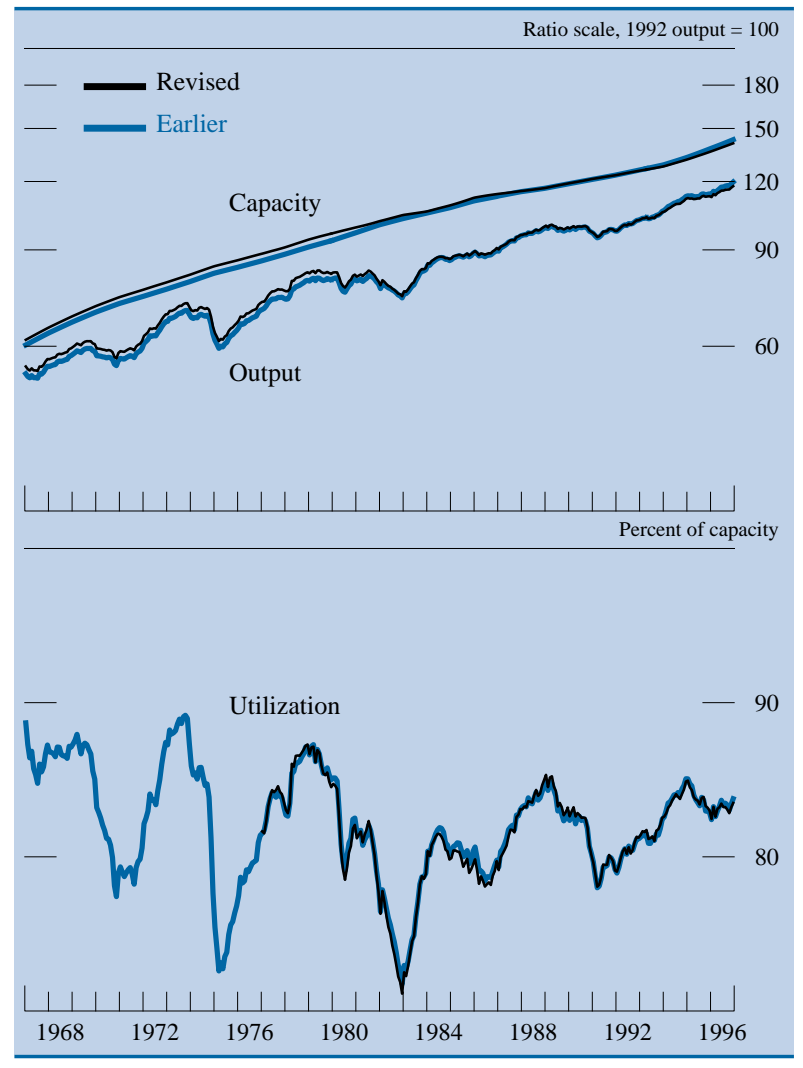

Note. Seasonally adjusted monthly data through December 1996. 
1. Revised growth rates of industrial production and capacity, and level of capacity utilization, 1967-96

\begin{tabular}{|c|c|c|c|c|c|c|c|}
\hline \multirow{3}{*}{ Item } & \multirow{2}{*}{\multicolumn{3}{|c|}{$\begin{array}{l}\text { Revised growth rate } \\
\text { (percent) }\end{array}$}} & \multicolumn{4}{|c|}{$\begin{array}{l}\text { Difference between revised and earlier growth rates } \\
\text { (percentage points) }\end{array}$} \\
\hline & & & & \multicolumn{2}{|c|}{ Total } & \multicolumn{2}{|c|}{$\begin{array}{l}\text { Due to the new } \\
\text { formulation }\end{array}$} \\
\hline & $1967-77$ & 1977-87 & 1987-96 & 1977-87 & 1987-96 & $1977-87$ & $1987-96$ \\
\hline \multicolumn{8}{|l|}{ Production } \\
\hline Total industrial . & 3.3 & 2.3 & 2.3 & -.3 & -.2 & -.3 & -.2 \\
\hline Manufacturing & 3.4 & 2.7 & 2.5 & -.5 & -.3 & -.5 & -.3 \\
\hline Excluding computers & 3.2 & 2.2 & 2.1 & .1 & -.1 & -.1 & -.1 \\
\hline \multicolumn{8}{|l|}{ Capacity } \\
\hline Total industrial & 3.5 & 2.4 & 2.2 & -.2 & -.2 & -.4 & -.1 \\
\hline Manufacturing & 3.6 & 2.8 & 2.5 & -.5 & -.3 & -.6 & -.2 \\
\hline Excluding computers & 3.5 & 2.2 & 2.2 & .1 & -.1 & -.1 & -.1 \\
\hline \multicolumn{8}{|l|}{$\begin{array}{l}\text { Capacity utilization } \\
\text { (level, end of period) }\end{array}$} \\
\hline Total industrial . & 83.9 & 82.7 & 83.2 & -.1 & -.2 & -.1 & -.7 \\
\hline Manufacturing & 83.3 & 82.7 & 82.2 & -.2 & -.1 & -.2 & -.7 \\
\hline Excluding computers & 83.3 & 82.9 & 82.0 & -.1 & .5 & -.2 & -.4 \\
\hline
\end{tabular}

NoTE. Growth rates are calculated as the average percentage change in the seasonally adjusted index from the fourth quarter of the first year specified to the fourth quarter of the last year specified. For 1967 the calculations begin in the

third quarter, and for 1996 the calculations in the last column end in the second quarter. The capacity utilization rates are for the fourth quarter of the last year specified.

1996, total industrial output grew at an average pace of about 2.3 percent per year-about $1 / 4$ percentage point less than previously estimated (table 1). The growth of industrial capacity was revised down nearly as much; consequently, the rate of total industrial capacity utilization was revised down only a fraction of a percentage point at the end of 1996. (See the summary tables in appendix A for details of the revised indexes.)

The downward revisions to production and capacity growth arise primarily from the introduction of the new formulation for those measures, which tends to reduce the influence of the fastest growing industries-such as computers-on aggregate growth. In particular, although the revised output and capacity indexes now show slower growth for total manufacturing, growth in manufacturing excluding computers is reduced only a bit as a result of introducing the new formulation (table 1).

The revisions for 1992-96 not only incorporate the new annual weighting formulation but also update source data. In particular, data from the Annual Survey of Manufactures of the Bureau of the Census account for most of the reduction of 1 percentage point in the growth in manufacturing output in 1994 (table 2). Since 1992, growth in manufacturing has averaged 3.8 percent a year, down 0.5 percentage point from the earlier estimates.

The largest revisions of the production indexes by market group - upward in consumer durable goods and downward in business equipment-relate to the treatment of computers; the downward revision in

2. Revised growth rates of industrial production and capacity, and level of capacity utilization, 1992-96

\begin{tabular}{|c|c|c|c|c|c|c|c|c|}
\hline \multirow{2}{*}{ Item } & \multicolumn{4}{|c|}{$\begin{array}{l}\text { Revised growth rate } \\
\text { (percent) }\end{array}$} & \multicolumn{4}{|c|}{$\begin{array}{c}\text { Difference between revised and earlier growth rates } \\
\text { (percentage points) }\end{array}$} \\
\hline & $1992-96$ & 1994 & 1995 & 1996 & $1992-96$ & 1994 & 1995 & 1996 \\
\hline \multicolumn{9}{|l|}{ Production } \\
\hline Total industrial & 3.5 & 5.7 & 1.8 & 3.7 & -.4 & -.9 & .2 & -.8 \\
\hline Manufacturing & 3.8 & 6.5 & 1.6 & 4.0 & -.5 & -1.0 & .2 & -.8 \\
\hline Excluding computers & 3.2 & 6.0 & .7 & 3.1 & -.2 & -.9 & .5 & -.1 \\
\hline \multicolumn{9}{|l|}{ Capacity } \\
\hline Total industrial & 2.8 & 2.5 & 3.3 & 3.7 & -.4 & -.3 & -.5 & -.3 \\
\hline Manufacturing & 3.1 & 2.7 & 3.7 & 4.1 & -.5 & -.5 & -.6 & -.4 \\
\hline Excluding computers & 2.6 & 2.3 & 3.1 & 3.3 & -.3 & -.3 & -.4 & -.1 \\
\hline \multicolumn{9}{|l|}{$\begin{array}{l}\text { Capacity utilization } \\
\text { (level, end of period) }\end{array}$} \\
\hline Total industrial ...... & $\cdots$ & 84.3 & 83.1 & 83.2 & . & -.4 & .2 & -.2 \\
\hline Manufacturing & $\ldots$ & 83.9 & 82.3 & 82.2 & $\cdots$ & -.4 & .2 & -.1 \\
\hline Excluding computers & . & 83.9 & 82.1 & 82.0 & . & -.2 & .5 & .5 \\
\hline
\end{tabular}

age change in the seasonally adjusted index from the fourth quarter of 1992 to the fourth quarter of 1996. Growth rates for years are calculated from the fourth 
equipment reflects both the new formulation and the reassignment of a portion of computer output (mainly personal computers for home use) from business equipment to consumer durable goods other than automotive products (tables A.3 and A.5). Among major industry groups, the large upward revisions in semiconductors and electrical machinery relate to the use of quality-adjusted price indexes for semiconductor components to develop new annual production benchmarks (tables A.4 and A.6).

The slower overall trend growth in production is reflected in the lower trend growth in the revised estimate of manufacturing capacity, which is also 0.5 percentage point below the earlier estimate for the period from 1992 to 1996 . (The effect of revisions of the production indexes on our capacity indexes is described in the section on methods.) The rate of manufacturing capacity utilization - the ratio of production to capacity - in the fourth quarter of 1996 is only 0.1 percentage point lower than the earlier estimate. Like the earlier estimates, the revised ones show that capacity utilization reached its most recent high at the beginning of 1995 and that pressures on industrial capacity have been lower since then.

Revisions to utilization rates are quite disparate among industries (table A.7). Substantial upward revisions in utilization in the fourth quarter of 1996 for miscellaneous manufacturing, apparel, aerospace and miscellaneous transportation equipment, and electrical machinery including semiconductors largely counterbalance the downward impact on utilization of the new annual weighting formulation and lower utilization rates for motor vehicles and parts, computers, and other industries.

\section{INDUSTRIAL DEVELOPMENTS IN THE 1990S}

The industrial sector entered the 1990s operating at a high level. Then, following the spike in oil prices that accompanied Iraq's invasion of Kuwait in August 1989, a rather shallow six-month contraction ensued. Output of durable manufactured goods fell 7 percent to a trough in March 1991 and then surpassed its previous peak in the fourth quarter of 1992, with the completion of the gradual recovery from the contraction.

During the four years since then, the industrial sector, led by gains in durable manufacturing, has continued to expand, with only a six-month pause after January 1995. During this expansion phase, output in durable manufacturing advanced at an annual rate of 6 percent; output at utilities, roughly $2 \frac{1}{2}$ percent; nondurable manufacturing, $1 \frac{11}{2}$ percent; and mining, 1 percent (table A.6). Despite the continuing expansion, productivity advances and the increased use of temporary employees have limited the hiring of permanent employees in industry. Employees on manufacturing payrolls numbered 18.3 million at the end of 1996 , up only 200,000 since 1992 and down 1 million since the late 1980s. Employment in nondurable manufacturing, where production growth had been slow, declined in 1995 and 1996.

\section{Production in the 1990s by Market Group}

The output of durable consumer goods helped fuel the recovery and expansion from the 1991 trough until 1994, with strong gains in light trucks, automobiles, appliances, and personal computers (chart 2 and table A.5). Since then, real output of home computing equipment, adjusted for quality improvements, has risen more than 30 percent per year, while output of consumer durables other than personal computers has flattened noticeably.

Assemblies of autos and light trucks hit a cyclical low in early 1991, climbed at a double-digit rate through early 1994, and then essentially flattened. Domestic assemblies of light vehicles averaged about 11.7 million units annually from 1994 to 1996 , while total sales, including imports, averaged nearly 15 million units.

Underlying the overall trend in U.S. production of light vehicles during the past decade were several important developments: the growth of U.S. assembly plants owned by Japanese manufacturers (transplants), which substantially cut imports of vehicles; quality improvements that made American-built vehicles more competitive; and the shift in the composition of overall output to light trucks, especially sport utility vehicles. Assemblies of light trucks in the United States, which averaged 33/4 million units in the late 1980s, reached 51/2 million in the second half of 1996; in contrast, automobile production has trended down from 8 million units in 1985-86 to just over 6 million units last year-despite the growth of transplants.

In contrast to the substantial growth in the output of consumer durables during the 1990s, the production of consumer nondurables grew at an annual rate of only about $1 \frac{1 / 2}{2}$ percent. Significant disparities in growth rates are apparent among the components of this group. Newspaper circulation trended gradually downward. Production of clothing fell about one-tenth in 1995 and early 1996 to a level near the recession low of 1990-91. Foods and tobacco grew 
2. Industrial production by market groups, 1987-96

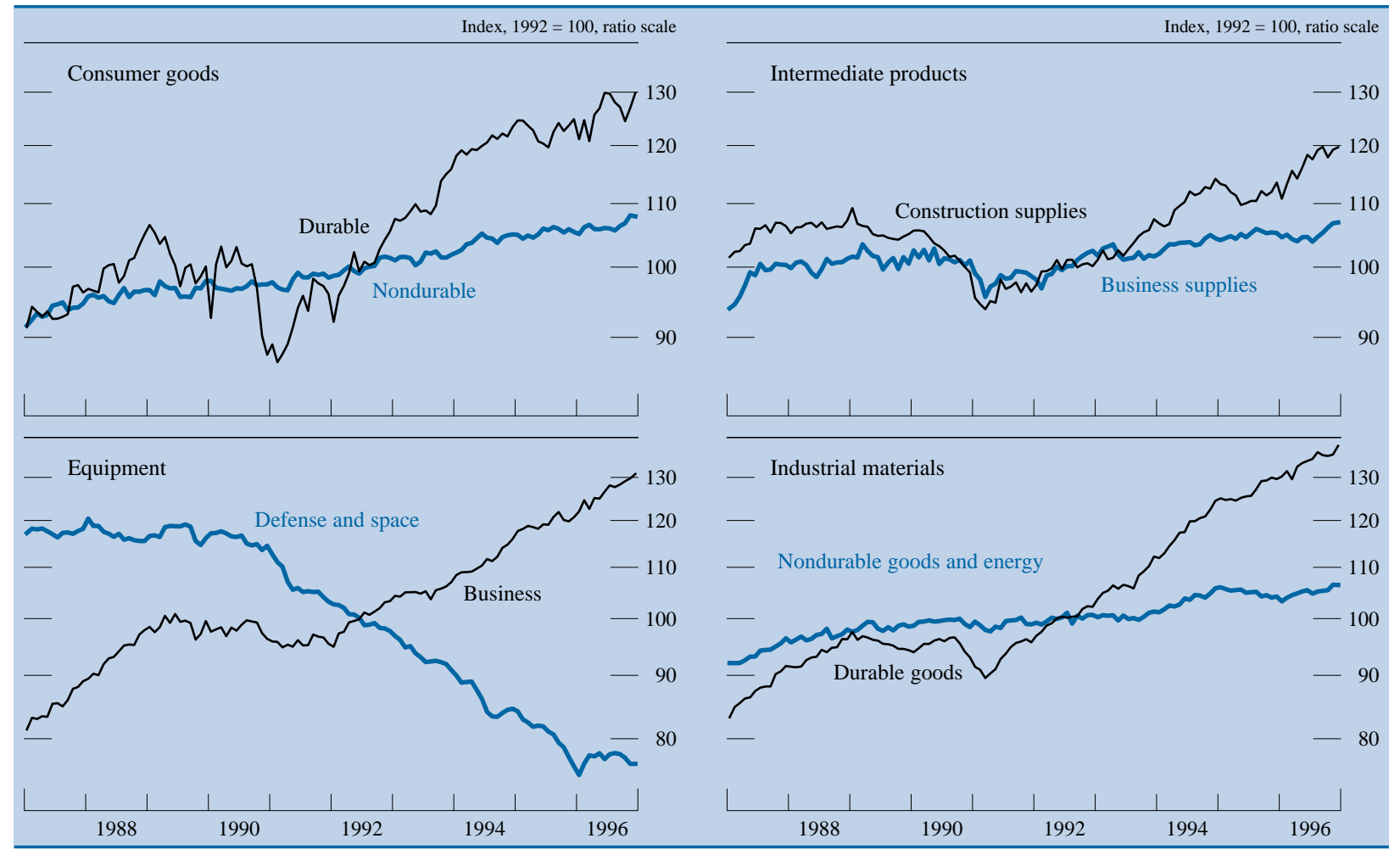

NotE. Seasonally adjusted monthly data through December 1996.

slowly overall. But production of drugs and medicines and output of paper products for the home exhibited strong growth.

The business equipment group lagged the cyclical improvement in overall IP but has been a major source of strength since early 1992. Led by a doubledigit annual rate of growth in the output index for information processing and related equipment, the output of business equipment advanced more than one-third through the end of 1996. The qualityadjusted output of computers nearly quadrupled over the period and accounted for more than one-third of the growth in business equipment. Excluding computers, output of business equipment grew about 25 percent.

Growth in the industrial equipment group was strong from early 1992 to mid-1995 and then flattened at a level that exceeded its 1989 cyclical peak by about 15 percent; however, the output of construction equipment-the fastest growing componentcontinued to rise in the second half of 1995 and 1996. The output of the "other equipment" group, which includes farm and service industry equipment and office furniture, also grew rapidly in 1993 and 1994 and then paused before rising in the latter half of 1996 to a level about one-tenth above that preceding the last recession.
Of the major subgroups within business equipment, only transit equipment exhibited practically no net production growth from 1991 to early 1996 as assemblies of business autos stagnated and the output of commercial aircraft and parts dropped sharply, particularly in 1993. Demand for business trucks strengthened considerably early in the expansion, but then in late 1995 and 1996, assemblies of heavy trucks and trailers weakened significantly. The output of transit equipment eventually pushed to new highs, but not until 1996, with the strong recovery in production of commercial aircraft and parts.

The reductions in real federal investment in defense and space equipment have cut the production index for such equipment, which includes military aircraft and parts, about one-third since mid-1989. The decline, which was quite rapid from 1991 through 1995, is estimated to have eased in 1996.

The output of construction supplies, which dropped more than one-tenth during the 1990-91 recession, did not recover to prerecession levels until late 1993 and early 1994. The recovery was slowed by high vacancy rates and the related weakness in the construction of multifamily residential buildings and nonresidential structures, particularly office and industrial buildings, that persisted into 1993. In contrast, single-family starts recovered much sooner and 
more robustly. From the end of 1993 through late 1996, the output of construction supplies advanced at an average annual rate of roughly 4 percent, despite a decline in the first half of 1995 that was correlated with a dip in housing starts.

The output of business supplies grew slowly in the 1990s. Although commercial and other sales of electric and gas utilities expanded solidly, output of paper business supplies and agricultural chemicals grew hardly at all, and newspaper advertising trended sharply downward.

In the 1990s, the production of materials for further industrial processing grew more rapidly than the output of finished goods. Producers of industrial materials comprise a large, diverse group that accounts for roughly 40 percent of total industrial production. Durable goods materials, such as steel, turbines, semiconductors, and parts used in computers, motor vehicles, and aircraft, account for more than half of industrial materials. The output of durable goods materials has increased more than 40 percent since the beginning of the decade. Not surprisingly, computer parts and semiconductors led the advance with double-digit annual growth rates. The strength in the output of durable goods materials was supported by gains since the 1990-91 recession in the output of steel, motors, and other parts used to make motor vehicles, appliances, and heavy equipment. However, the weakness in the aerospace industry was a restraining influence until recently.

In comparison with the gains in durable goods industries, the growth in the production of nondurable goods materials and energy materials was anemic. The downtrend in crude oil production, particularly in Texas and Alaska, tended to offset recent gains in the production and use of natural gas and coal. Declines in the production of residual fuel oil, nuclear materials, and coke similarly offset a moderate rate of increase in the generation of electricity. Within nondurable goods materials, growth in textile, paper, and chemical materials was quite slow on balance from early 1989 until the third quarter of 1993 and then grew strongly for a time, only to fall back in 1995 . From the start of the decade through late 1996, the output of this group grew at an annual rate of only $1 \frac{1}{2}$ percent. In this group, plastics resins, synthetic rubber, and paperboard were relatively strong performers.

\section{Capacity and Utilization in the 1990s}

So far in the 1990s, the rate of capacity utilization in total industry has reached neither the extreme highs nor the extreme lows of the 1970s and 1980s. This moderation reflects an acceleration in the growth of capacity as well as the relatively mild industrial recession at the start of the decade and the temperate pace of the expansion that has lasted nearly six years. An acceleration in the growth of capacity in recent years has accommodated this lengthy expansion without signs of substantial pressures on productive capacity. The low in utilization, 78.1 percent, occurred at the production trough in early 1991 and was well above the previous low of 71.1 percent in late 1982. Over the years of expansion after 1991, utilization reached a high of 84.9 percent in late 1994 and early 1995 (table A.1). Although this level was near the high recorded in the late 1980s, it was noticeably below the cyclical highs of the 1970s. Utilization eased in 1995 and ended 1996 at about $83 \frac{1}{2}$ percent-still more than a percentage point above the long-term average.

Within manufacturing, utilization rates in late 1996 were relatively high for industrial machinery and equipment, especially computers, and for a number of primary-processing industries including petroleum refining, rubber and plastics products, fabricated metal products, and primary metals, such as steel (table A.7). By contrast, apparel products, printing and publishing, and leather and products had utilization rates that were below their longer-run averages.

As the current expansion has continued, real investment expenditures for industrial plant and equipment have increased rapidly and contributed to a faster rate of growth of capacity. The annual rate of growth of manufacturing capacity roughly doubled, from approximately 2 percent early in the decade to more than 4 percent in 1996; in durable manufacturing, capacity growth tripled to more than 6 percent (table A.8). High and rising rates of growth of capacity were, of course, most evident for computers and semiconductors, but the acceleration was large even for more slowly growing industries such as steel, fabricated metals, and lumber. Growth in capacity in nondurable manufacturing has remained low.

In mining, the long-term decline in capacity moderated as the drop in available drilling rigs, which began in 1983, lessened substantially. Utilization in oil and gas well drilling, although far below earlier peaks, rose to its highest level since 1982. Recent increases in offshore drilling also helped to maintain reserves and offset the ongoing decline in oil and gas extraction from aging oil fields. Capacity growth in the rest of mining and in utilities was relatively modest. Output growth at utilities exceeded capacity growth over the past ten years; as a result, the excess capacity that developed after the energy shocks in the 1970s and early 1980s has essentially been eliminated. 


\section{NEW AGGREGATION METHODS}

As indicated, the most important improvement for this revision is the introduction of new aggregation methods from 1977 onward. As before, the contribution of an individual industry to total output or capacity is based on the value added by that industry. Now, however, we update the value-added weights annually, rather than quinquennially, and keep them concurrent with production. The aggregation method for IP, a version of the Fisher-ideal index formula, is more firmly rooted in economic theory and eliminates a source of upward bias in the previous estimates. Some of the same issues are addressed in the recent reformulation of the featured measure of real output published by the U.S. Department of Commerce's Bureau of Economic Analysis (BEA). ${ }^{1}$

Measures of industrial output can be distorted if the relative valuations of the component series are out of date by even a few years. In order to minimize this bias, for the revised production index, annual weights are estimated through the most current periods even though comprehensive data on value added lag a few years. These estimates are developed from related information on producer prices or, if required, by statistical extrapolation.

The aggregation of capacity and capacity utilization is accomplished by a generalization of the method introduced in the 1990 revision of those series. The approach is discussed more fully in the accompanying box, "Aggregation of Industrial Production and Capacity Utilization-A Technical Note," which presents the algebraic formulations of the new industrial production and capacity utilization measures.

\section{Industrial Production}

To represent the changing relative price and cost structure of industries, the industrial production index was previously built, for the most part, in five-year chronological segments, each with value-added weights drawn from the first year of the segmentthe year of the quinquennial Census of Manufactures, the underlying data source for value added. Chaining the segments together formed a continuous index expressed as a percentage of output in a reference year. Although the periodic introduction of new

1. See J. Steven Landefeld and Robert P. Parker (with Jack E. Triplett), "Preview of the Comprehensive Revision of the National Income and Product Accounts: BEA's New Featured Measures of Output and Prices," Survey of Current Business, vol. 75 (July 1995), pp. 31-38, and the references contained therein.
3. Proportion of computer output in industrial production, 1977-96

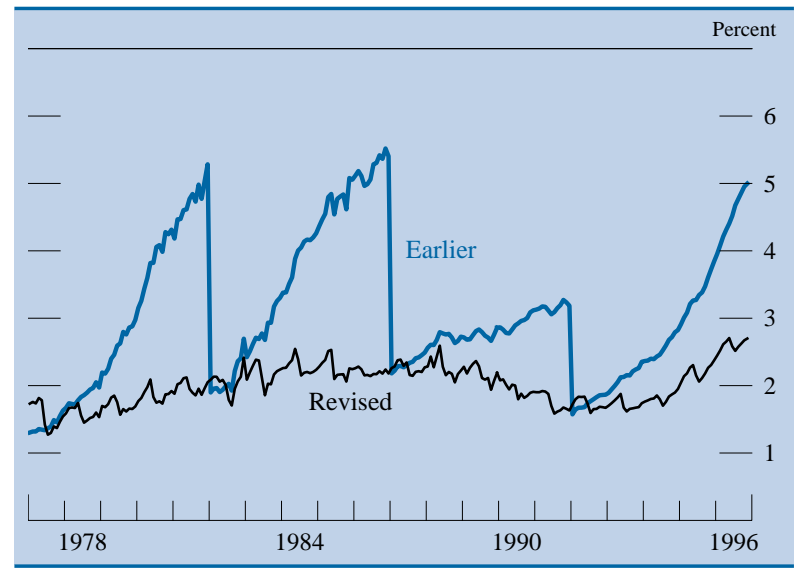

weight years ensured that the IP index reflected the evolution of relative prices over time, the weights of very fast growing industries, such as computers, became outdated quickly and caused output growth to be overstated.

In general, a measure of real output based on relative prices of a more recent year increases less rapidly than a measure based on relative prices of an earlier year. This characteristic result, which has long been observed in the construction of index numbers, exists because the goods for which output grows rapidly tend to be those that are characterized by declining relative prices and production costs. ${ }^{2}$ Economic theory suggests that the preferred measure of output growth between two periods is a geometric average of two indexes: one weighted according to the relative price structure of the earlier period and the second weighted according to the relative price structure of the later period. This result is called a Fisher-ideal index. Quantity measures derived as Fisher-ideal indexes usually grow more slowly than quantity measures derived using just the earlier period's prices as weights. Even though the previous IP index used a progression of valuation periods, it still overstated output growth because it used prices of a given year to weight quantities for some number of subsequent years.

An example of how this bias was manifested in the earlier index is illustrated by the pattern of the proportion of computer output in industrial production (chart 3). During the interval between the censuses,

2. For example, see the discussion and results of the use of alternative weight years for industrial production in Kenneth Armitage and Dixon A. Tranum, "Industrial Production: 1989 Developments and Historical Revision," Federal Reserve Bulletin, vol. 76 (April 1990), pp. 188-204 (especially pp. 201-03). 
the relative proportion of an industry in IP equaled its base-period proportion multiplied by its growth since the base year relative to the growth of total IP. Thus the share of an industry grew (or declined) along with its relative gain (or loss) in production, regardless of relative price movements. Under the earlier aggregation method, with base-period weights fixed at 1977, 1982,1987 , and 1992, the current proportion of computer industry output grew in intervening years along with its relative gain in production until a new weight year was introduced. It would fall back with the introduction of new weights because the industry's value added, measured in current dollars, did not rise nearly as steeply as did its real output. The revised index eliminates the exaggerated saw-tooth pattern of the computer share by updating the industry's valueadded proportion-and its implied relative priceeach year. ${ }^{3}$ With weights updated annually, an industry's share fluctuates much less over time, but it will rise, for example, when a relative increase in an industry's real output is not offset by a proportionate relative decline in its value added per unit of output.

The revised IP index is called an annually weighted Fisher index. In the new formulation, the weights are expressed as unit value added (a "price") to facilitate the aggregation of IP as an annually weighted Fisher index for the recent period. Generally, the unit valueadded measures track broad changes in corresponding producer prices and evolve considerably more slowly than the corresponding real output (or than value added itself, which contains both quantity and price-cost elements). ${ }^{4}$ Therefore, even though the value-added data are available only after a lag of about two years (and sometimes longer), the weights required for aggregating IP in the most recent period can be (1) estimated from available data on producer prices through the most recent year and (2) extrapo-

3. The IP index for computers was first benchmarked to an annual index of real output derived using a hedonic price index for computers in a revision published in April 1990 that affected data from 1977 onward. Although the total IP index and its major industry and market subtotals before 1977 remain as previously formulated, total IP growth before 1977 is not noticeably overstated from the effects of declines in the relative price of computers for those years. The growth trend from 1967 to 1977 of manufacturing IP and of manufacturing IP excluding computers was similar (table 1). Moreover, the results of this revision suggest that aside from computers, from 1977 onward relative price movements among components of the earlier IP index caused only a small overstatement of the trend growth of overall industrial production.

4. For example, for fourteen of the twenty two-digit industry groups in manufacturing, more than 50 percent of the variance of the change in value added is explained by the change in the IP index for the industry, and, in simple regressions, the coefficient on the change in IP is not significantly different from 1 for these fourteen industries. The notable exceptions to this pattern are the food, petroleum, and paper industries.
4. Relative unit value added in industrial production, 1977-96

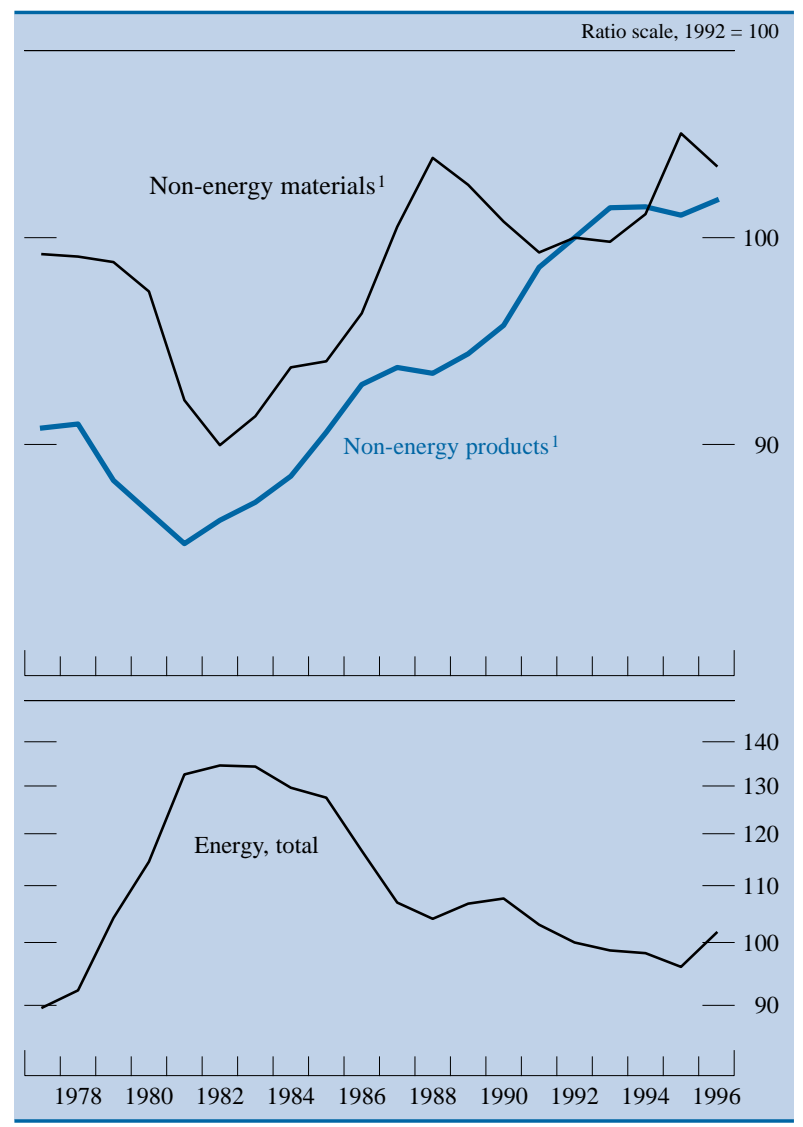

1. Non-energy materials and non-energy products exclude computers and semiconductors.

lated for the following year, given the persistence of many relative price trends.

The relative unit value added of the combined series for computers and semiconductors in total IP declines about $13 \frac{1}{2}$ percent per year, on average, from 1977 to 1987 , and by more than 10 percent, on average, since then. If the annual weights for IP were not estimated through the current period and this relative price of computers and semiconductors was held fixed for three years rather than allowed to continue its decline, the most recent IP estimates would overstate growth by about $1 / 2$ percentage point at an annual rate. Within the index, aside from computers and semiconductors, the basic trends in relative unit value added for non-energy products, non-energy materials, and total energy can also diverge from one another at times (chart 4), and such developments are reflected in the timely producer price figures.

The new formulation for monthly IP is computationally more complex than the previous formulation: Each month's computation involves weights from 


\section{Aggregation of Industrial Production and Capacity Utilization-A Technical Note}

\section{Industrial Production}

An individual IP series, $I_{n}$, represents a quantity of output for a period $n$ expressed relative to the quantity produced in a reference period 0 , that is, $I_{n}=\left(q_{n} / q_{0}\right)$. The previous practice was to compute an IP aggregate, either the total index or its major market and industry subtotals, $I_{n}^{A}$, as a weighted relative quantity,

$$
I_{n}^{A}=\frac{\sum I_{n} v}{\sum v},
$$

using value added, $v$, to indicate the relative importance of the individual quantities. As a result, the IP index was expressed as a value-added weighted sum of its components, $I_{n}^{A}=\Sigma I_{n} w$, where $w=v / \sum v$. The previous IP index generally was built in five-year segments, with the initial year of each segment used as the base year for weights; the segments were linked together over time to form a continuous index expressed as a percentage of output in a reference year.

The previous IP index was called a linked-Laspeyres index. Consider that value-added weights have both quantity and price-cost elements. With $v=q_{0} p_{0}$, each segment of the former IP index could also be expressed as the weighted aggregate quantity, $\Sigma q_{n} p_{0} / \Sigma q_{0} p_{0}$. This is a Laspeyres quantity index, which shows changes in quantities with prices held fixed at base-year values.

Laspeyres quantity measures usually overstate output growth as one moves further from a base period. This occurs because, over time, the quantities that increase the most tend to be those whose prices have increased, relatively, the least. As a result, the use of weights from an earlier period increasingly exaggerates the relative importance of the fast growing components as time passes. Conversely, quantity measures derived from a Paasche index, which is expressed as $\Sigma q_{n} p_{n} / \Sigma q_{0} p_{n}$ and shows changes in quantities with prices at current period values, usually understate the output change.

Economic theory suggests that the preferred measure of quantity change is a geometric average of a Laspeyres index and a Paasche index. This result is called a Fisher-ideal quantity index. Quantity measures derived as Fisher indexes register increases (or decreases) that fall between those derived from either a Laspeyres or a Paasche formulation.

The new formulation for aggregating industrial production is based on a Fisher index that updates the weights every year (but not every month). Source data on value added are available annually.

The "price" weights used in the new IP formulation are annual unit value added, that is, value added (an annual series in dollars) divided by an IP index for the year, $P_{y}=v_{y} / I_{y}$. Technically, the new formulation for monthly IP is a variant of the Fisher index described above in that it uses averages of monthly output growth estimates weighted by earlier and later year prices. Like the Bureau of Economic Analysis, which introduced this type of Fisher variant for its quarterly estimates of real GDP, the weights will be updated in the middle of the year. A convenient way of expressing this timing is that a monthly IP aggregate in month $m$ is computed with weights from the years containing the months $(m-6)$ and $(m+6)$.

The new formula for the growth of monthly IP in month $m$ is given by

$$
\frac{I_{m}^{A}}{I_{m-1}^{A}}=\sqrt{\frac{\sum I_{m} P_{y(m-6)}}{\sum I_{m-1} P_{y(m-6)}} \times \frac{\sum I_{m} P_{y(m+6)}}{\sum I_{m-1} P_{y(m+6)}}},
$$

where the subscript, $y(m)$, denotes "year containing month $m$." The new total IP index, as well as its major market and industry subtotals, are computed as the cumulative product of a monthly series of these growth estimates from 1977 onward. The monthly estimates for each aggregate are controlled so that their annual growth rates conform to the growth rates of an annually weighted Fisher index derived using annual data.

The revised monthly IP index and its major aggregates are computed as annually weighted Fisher indexes even for the most recent period. For the more recent estimates, Federal Reserve extrapolations of the annual weights are used.

With the more complex formulation of the new IP index, the Federal Reserve will provide users with additional time series representing the proportionate contribution of changes in a component index to the change in the total index. These statistics, which for a month are the average of implicit value-added shares for the component in month $m-1$ based on earlier and later-year unit value added, represent the linear term of a Taylor's series expansion of the formula for monthly IP growth given above.

\section{Capacity and Capacity Utilization}

An individual capacity utilization series, $U_{n}$, is a ratio of the actual level of output to a sustainable maximum level of output or capacity. The output figures are indexes of industrial production, and the related capacity series are derived from survey data on utilization and capacity to provide an integrated system of output, capacity, and utilization measures for the industrial sector.

The aggregation of capacity and capacity utilization rates presents distinct issues in that they are constructed and defined in relation to industrial production: Given that $U_{n}=q_{n} / c_{n}$ and that $I_{n}=q_{n} / q_{0}$ is a production index, then the capacity index, $C_{n}$, consistent with the production index is $c_{n} / q_{0}=\left(q_{n} / q_{0}\right) / U_{n}$, or, $C_{n}=I_{n} / U_{n}$. Given a production 


\section{Aggregation of Industrial Production and Capacity Utilization-Continued}

aggregate, it is desirable to preserve this relationship for related capacity and capacity utilization aggregates. That is, we want $C_{n}^{A}=I_{n}^{A} / U_{n}^{A}$, or equivalently, $U_{n}^{A}=I_{n}^{A} / C_{n}^{A}$ to hold after aggregation.

The revised utilization aggregates are given by

$$
U_{n}^{A}=\frac{\Sigma v}{\Sigma\left(v / U_{n}\right)},
$$

which expresses a utilization aggregate as the ratio of the components' aggregate actual value added to their aggregate value added at capacity. This expression is implemented in terms of a production index for a year, that is, with value added (an annual series in dollars) as $P_{y} I_{y}$, and given that $U_{y}=I_{y} / C_{y}$, then a utilization aggregate is calculated as

$$
U_{y}^{A}=\frac{\sum P_{y} I_{y}}{\sum P_{y} C_{y}},
$$

which is equivalent to the expression,

$$
U_{y}^{A}=\sum \frac{P_{y} C_{y}}{\sum P_{y} C_{y}} U_{y} .
$$

Thus, the aggregate utilization rates are equivalent to capacity-weighted aggregates of individual utilization rates; that is, they are a combination of component utilization rates weighted by proportions that reflect the component's share in the aggregate current value of production at capacity.

With the weights for production now updated annually, the utilization aggregates are now derived from component measures annually. The new monthly capacity aggregates are constructed in three steps: (1) utilization aggregates are calculated on an annual basis through the most recent full year; (2) the annual aggregate capacity is derived from the corresponding production and utilization aggregates; (3) the monthly capacity aggregate is obtained by interpolating with an annually weighted Fisher index of its constituent monthly capacity series. For the very recent period, since the most recent full year, each monthly capacity aggregate is extrapolated by this same Fisher index, adjusted by a factor that accounts for the differences in their relative growth rates.

Previously, the appropriate relationships for capacity utilization aggregates were exact only in each weight-base year. When a new base year was introduced into the production and capacity measures, however, each utilization aggregate for the new base year was calculated with weights for that year and the previous base year. The differences were often sizable for aggregates that contained components with divergent relative prices, such as computers or energy materials. As a result, the aggregate capacity indexes between the two base years were then smoothly adjusted so that no discontinuity in the utilization aggregate occurred. ${ }^{1}$

Just as using the ratio of a linked-Laspeyres IP index to a linked-Laspeyres capacity index might distort aggregate utilization, so using the ratio of a Fisher IP index to a Fisher capacity index might produce a similar distortion. Consequently, the new capacity aggregates are not annually weighted Fisher indexes of the individual capacity series. If a capacity aggregate were to be formulated in a way similar to that of a production aggregate and if a utilization aggregate were calculated as a ratio of the two separately aggregated series, a noticeable distortion in this utilization aggregate would occur if two conditions are present: (1) the relative price of a component industry changes significantly, and (2) the utilization rate of the component differs from the average of the group. ${ }^{2}$ In general, only the direct aggregation of the individual proportional relationships preserves the appropriate aggregate for capacity utilization.

The major advantage of the new procedure is that utilization rates through the current period are aggregated with capacity proportions in current period values. Previously, the more recent capacity proportions were valued in prices of the most recent weight-base year, which could introduce distortions in current measures of capacity utilization. ${ }^{3}$

1. See Richard D. Raddock, "Recent Developments in Industrial Capacity and Utilization," Federal Reserve Bulletin vol. 76 (June 1990), pp. 411-35.

2. To illustrate the distortion that may result, consider a two-industry example. One industry grows slowly, another industry, such as computers, grows very fast and its unit value added is falling. If computer manufacturers typically operate at a higher rate of utilization than does the other industry, their share of overall capacity will be less than their share of actual production. The lower capacity share for computers implies a slower rate of growth for the Fisher index of combined capacity than for the Fisher index of combined production. Assume that the computer manufacturers produce 50 percent of the total value added (in current dollars) of the two industries but maintain only 45 percent of the total capacity (also in current dollars). If the actual and capacity output of computers in real terms were growing 20 percent per year (with no growth in nominal value added), and if the real output and capacity of the other industry were not growing, the Fisher production aggregate of the two industries would grow about 10 percent per year $(0.50 \times 0.20+0.50 \times 0.00)$, and the Fisher capacity aggregate would grow about 9 percent per year $(0.45 \times 0.20+0.55 \times 0.00)$. The ratio of the Fisher IP index to the Fisher capacity index would increase by 1 percent every year, and the aggregate utilization rate would increase without bound.

3. That is, the utilization aggregate for a month since the most recent weight-base year was computed as the ratio of a linked-Laspeyres production index to a linked-Laspeyres capacity index, which yielded,

$$
U_{m}^{A}=\sum \frac{P_{0} C_{m}}{\sum P_{0} C_{m}} U_{m},
$$

where $P_{0}$ is unit value added in the base year. 
two years. In addition, the unit value-added figures have little intuitive meaning as weights. Users (and estimators) of the former IP index always found its aggregation to be more conveniently viewed in terms of value-added shares rather than prices because the contribution of a component index to the total index was seen directly with value-added shares.

With the new Fisher formulation for IP, the growth rate of the total index can still be viewed as a value-added weighted sum of its components' growth rates. Specifically, the growth of a component index multiplied by its share of value added gives its approximate contribution to the growth of the total index (table A.9). To supplement the information on value-added proportions for the previous year that are shown in the statistical release, the Federal Reserve now provides corresponding (and more exact) monthly statistics representing the proportionate contribution of a monthly change in a component index to the monthly change in the total index-for example, the computer share shown in chart 3 . With the additional statistics, many calculations frequently performed by users of the former index are achieved with the revised index in a similar fashion. ${ }^{5}$

This revision also updates the formulation used for the supplementary series on the gross value of products leaving the industrial sector, which are expressed in dollars. The industrial production data on gross value of products, which cover the period since 1977, continue to be aggregated from production indexes for products using weights based on the market value of production. (The materials series are excluded to avoid double-counting.) Previously, they were combined with gross-product weights drawn entirely from the year 1992. They are now derived as annually weighted Fisher indexes, with gross-product weights updated annually and expressed in 1992 dollars after aggregation.

\section{Annual Weights}

Annual weights for the aggregation of IP and capacity utilization were derived from annual estimates of

5. An example of a typical calculation is as follows: Assume a 10 percent jump in the output of the motor vehicle and related industries and that these IP components account for 5 percent of total index points in value-added terms in the previous period. Then the contribution of this development to the percentage change in total IP for a given month is $0.05 \times 0.10=0.005$, or $1 / 2$ percent for the month. Current estimates and historical time series of the monthly proportions (the 5 percent in the example) for IP components shown on tables 1 and 2 of the Federal Reserve's statistical release G.17 "Industrial Production and Capacity Utilization" are available with the revised index. (See box, "Data Availability.") industry value added. Annual weights for the aggregation of gross value of products are derived from estimates of the total market value of production. The sources of these figures are the same as those used for the periodic updating of weights for the earlier measures. ${ }^{6}$

For the most part, source data on value added were available through 1994 at the time the revision was compiled (in late 1996). To construct output, capacity, and capacity utilization using the new formulations through the most recent period requires unit value added for more recent years. For example, to compute IP growth as an annually weighted Fisher index for the second half of 1996 requires unit value added for 1996 and 1997. The estimates for recent periods were obtained in two steps. First, industry producer prices from the Bureau of Labor Statistics, which were available through the third quarter of 1996 at the time the revision was compiled, were extrapolated to obtain annual averages for 1996 and

6. Annual value-added data are reported in the quinquennial Census of Manufactures and the Annual Survey of Manufactures of the Bureau of the Census. Value added for electric and gas utilities are computed from annual revenue and expense data reported by the Department of Energy and the American Gas Association. Valueadded data for mining industries are available only every five years from the Census of Mineral Industries. Estimates of unit value added for intervening years are derived from related final product prices, either a producer price index from the Department of Labor's Bureau of Labor Statistics or a spot price for selected commodities such as crude oil, gold, or silver. Annual data on the total value of production (shipments plus inventory change, including the value of excise taxes) required for the gross value of product aggregates are derived from these same sources.

\section{Data Availability}

Files containing the revised data and the text and tables from the supplement to the G.17 release, "Industrial Production and Capacity Utilization: Historical Revision," are available on the Board's World Wide Web site at http://www.bog.frb.fed.us. Files will also be available through the Economic Bulletin Board of the Department of Commerce; for information, call (202) 482-1986. Diskettes containing either historical data (through 1985) or more recent data (1986 to those most recently published in the G.17 release) are available from Publications Services, Board of Governors of the Federal Reserve System, Washington, DC 20551, or phone (202) 452-3245.

This article will be available on the Board's Web site at (http://www.bog.frb.us/releases/G17/About.htm). 
1997. Second, the unit value-added measures were extrapolated based on these annual averages of industry producer prices. Later this year, the formulation will require weights drawn from 1997 and 1998; at that time source data through 1995 will be available, and the same procedures will apply.

\section{NEW METHODS FOR INDIVIDUAL PRODUCTION AND CAPACITY SERIES}

The revision also incorporated improvements in the composition of selected IP market aggregates and enhancements to the structure of selected production and capacity series. As part of the revision from 1992 onward, monthly source data for all IP seriesphysical product data and measures of inputs to production-were updated to reflect revisions by the data providers and were adjusted by the Federal Reserve to eliminate seasonal, calendar, and holiday variation. ${ }^{7}$ The revised IP series reflect further adjustments of their annual averages to benchmark indexes derived from more comprehensive and newly available annual source data.

The revision to the Federal Reserve capacity estimates incorporated revised measures of industry capital input and detailed data from the Census Bureau's Survey of Plant Capacity for 1993 and 1994. No new broad survey results on capacity utilization rates beyond 1994 or on business investment plans beyond those first reported for 1996 were available for this revision. For the 1997 annual update, the Federal Reserve will have new results from the Survey of Plant Capacity for the fourth quarters of 1995 and 1996.

\section{Modifications to Series}

To improve the IP market aggregates, the portion of the output of computer and office equipment (SIC 357) designated as final product is now further split from 1982 onward into production of consumer goods, mainly personal computers for home use, and business equipment. The split is accomplished with expenditure data from the national income and product accounts. Formerly, all of the final product of the

7. For a summary of the Federal Reserve methods for seasonally adjusting the source data used to construct the index of industrial production, see Richard D. Raddock, "A Revision to Industrial Production and Capacity Utilization, 1991-95," Federal Reserve Bulletin, vol. 82 (January 1996), pp. 16-25 (especially pp. 23-24). computer industry was assigned to business equipment. (As in the earlier index, the industry's semifinished product is allocated to the materials market group.)

To improve coverage and reliability, monthly source data for five IP series were modified. With these changes, the monthly IP index now comprises 264 series for the period since 1992, and the proportion that is derived from physical product data rises 2 percentage points, in 1994 value-added terms, to 42 percent.

Portions of two equipment series, farm equipment (SIC 352) and construction and mining equipment (SIC 3531-3), which were based on input data, now make up two new series derived from monthly production estimates reported in Stark's Off-Highway Ledger. A weighted average of assemblies of combines and two types of tractors is the basis for the new farm equipment series, which represents SIC 3523. The remaining portion of the former series, lawn and garden equipment (SIC 3524), is represented by production worker hours and, with this revision, assigned to the consumer durable goods market group. The new construction equipment series, which represents SIC 3531, is constructed using a weighted average of assemblies of crawlers, wheel loaders, skid steer loaders, wheel tractors, and other construction equipment. Production worker hours are the basis for the remaining portion of the former series, mining and oil and gas field equipment (SIC 3532-3). The revised IP index incorporates these new equipment series beginning in 1987.

Before the current revision, the monthly output of original equipment parts for new motor vehicles, a portion of the total motor vehicle parts industry (SIC 3714), was represented by data on production worker hours at parts plants and motor vehicle assemblies. The series from 1992 onward now derives from monthly production estimates reported in Stark's Component Ledger. The new series is constructed using a weighted combination of gas engines, transmissions and axles (on-highway), and brakes. These components cover more than 40 percent of the total value of production in SIC 3714 and most of the original-equipment parts subcomponent.

Production of medium and heavy trucks, formerly a single component of business trucks, is now represented by separate series for medium-weight (gross vehicle weight of 14,001-33,000 pounds) and for heavy trucks $(33,001$ pounds and more) based on the same monthly production figures as previously used (Ward's Automotive Reports) in combination with information on factory shipments by detailed weight class reported by the American Automobile Manu- 
facturers Association. Similarly, capacity series for medium-weight trucks and another for heavy trucks and trailers were developed from the same sources; movements in the output of truck trailers are highly correlated with the output of heavy trucks.

Output of stone, sand, and gravel mining (SIC 141-2 and 144), formerly an input-based IP series, is now derived from quarterly production data reported by the Department of the Interior. These data, which cover most of the output of this industry, are interpolated to a monthly frequency and incorporated in the index beginning in 1992.

\section{Updated Data and New Production Benchmarks}

The regular updating of source data for industrial production includes the introduction of annual data from the Annual Survey of Manufactures for 1994 and selected Current Industrial Reports for 1995, both published by the Bureau of the Census. Available annual data on mining for 1994 and 1995 from the Department of the Interior were also introduced. Individual IP series incorporate revisions to the monthly indicators (either physical product data, production worker hours, or electric power usage) back to 1992. Seasonal factors for electric power and most physical product series were calculated on the basis of data through mid-1996; for production-worker hours and the unit counts of motor vehicle assemblies, seasonal factors were updated with data through October 1996. Productivity relationships used to extrapolate input-based IP series beyond 1994 or 1995 were updated using the revised output and input data.

With this revision, the annual updating of the individual IP series for manufacturing from 1992 onward reflects the incorporation of annual benchmarks of real output that are formulated as annually weighted Fisher indexes. While the vast majority of individual series were not revised for the years from 1977 to 1991, the new or modified series described earlier were adjusted to benchmarks formulated as annually weighted Fisher indexes from the initial year of the series. The sources for the basic data used to construct the new annual IP benchmarks in this revision are the same as those used for calculating the earlier benchmarks.

For this revision, the annual IP benchmark quantity indexes for semiconductors and related components and for computers and office equipment incorporate improvements from 1977 onward. The IP index for semiconductors and related components
(SIC 3672-9) was benchmarked to an annual index of real output that incorporated a quality-adjusted price index for domestically produced integrated microcircuits (the major product of SIC 3674, which is the largest industry in the broader IP grouping). Board staff constructed this index from detailed price indexes for selected semiconductor components, mainly memory and logic chips, developed by the BEA as part of its recent comprehensive revision of the national income and product accounts. The BEA also revised its quality-adjusted price index for computers for that revision, and the IP benchmark index for computers and office equipment incorporates those results.

\section{Revised Estimates of Industrial Capacity}

The capacity utilization estimates fully incorporate the more detailed data from the latest Census Survey of Plant Capacity issued in September 1996, which provided revised utilization rates for manufacturing industries for the fourth quarters of 1989 to 1994. Preliminary results through 1994 from the Census survey had previously been incorporated in the Federal Reserve estimates of capacity and utilization. Revised or newly available estimates of capacity in physical volume (number of units, tons, barrels, and so forth) for selected industries for 1992-96 are also incorporated.

Measures of industry capital input, which are used in estimating manufacturing capacity, were updated with Federal Reserve estimates of manufacturers' real net capital stocks that are now built from investment data expressed in chained 1992 dollars; formerly, the net capital stocks were derived from investment flows in constant 1987 dollars.

Within manufacturing, those capacity indexes that are derived from the Census survey and estimates of capital input have been revised back to 1977; as a result, capacity utilization rates for manufacturing have been revised from January 1977 onward. ${ }^{8}$ Capacity growth and utilization rates for mining and utilities have essentially been updated only in the 1990s, as have those manufacturing series derived from capacity and output data in physical units.

After a revision of the industrial production indexes, the individual capacity indexes must typically also be revised because capacity is calculated from industrial production and survey data on utiliza-

8. Some additional small changes to aggregate capacity utilization rates for the 1967-76 period were made to improve consistency with the new estimates from 1977 onward. 
tion rates. For example, in this revision, the production index for semiconductors shows much faster growth because of a change in the methodology of measuring its output; consequently, the related capacity index (maximum output) had to be similarly revised; otherwise, output growth far in excess of capacity growth would yield a time series of implausible utilization rates. In many instances in manufacturing, we estimate a single capacity series to match a number of the individual production series. In such cases, the new annual weighting formulation affected the estimated growth of production and was a factor in the reestimation of individual capacity series. For the most part, these are series derived from industrial production, data on utilization rates from the Survey of Plant Capacity, and Federal Reserve estimates of capital input.

To construct an individual capacity index, we first calculate preliminary, implied end-of-year indexes of industrial capacity by dividing a production index by a utilization rate obtained from a survey for that end-of-year period. These ratios are expressed, like the indexes of industrial production, as percentages of production in a comparison base year, currently 1992, and they give the general level and trend of the capacity estimates. ${ }^{9}$ The Federal Reserve's actual capacity indexes combine these preliminary indexes with information from alternative indicators of annual capacity change; these alternatives include capacity data in physical units and estimates of capital input. In general, the actual capacity indexes are proportional to fitted values from regressions that reflect both the trend growth of capacity implied by the survey data and the annual changes of the alternative

9. Each implied capacity index number is an estimate of a sustainable maximum level of output expressed as a percentage of actual output in 1992. Thus, if in December 1992 the production index is 100 and a related utilization rate from a survey is 80 percent, then the implied capacity index is $100 / 0.8=125$.

The capacity indexes capture the concept of sustainable practical capacity, which is defined as the greatest level of output that a plant can maintain within the framework of a realistic work schedule after taking account of normal downtime and assuming sufficient availability of inputs to operate the machinery and equipment in place. Both the questions asked in the broad Census survey and the narrower surveys of selected industries are generally consistent with this definiton of capacity. The concept itself generally conforms to that of a full-input point on a production function, with the qualification that capacity represents a realistically sustainable maximum, rather than some higher unsustainable short-term maximum. See Carol Corrado and Joe Mattey, "Capacity Utilization," Journal of Economic Perspectives (forthcoming, Winter 1997).

In the absence of utilization rate information for an industry, which is the case for a few series in mining, trends through peaks in production are used to estimate capacity output for that industry.
5. Change in manufacturing capacity and capital input, 1967-96

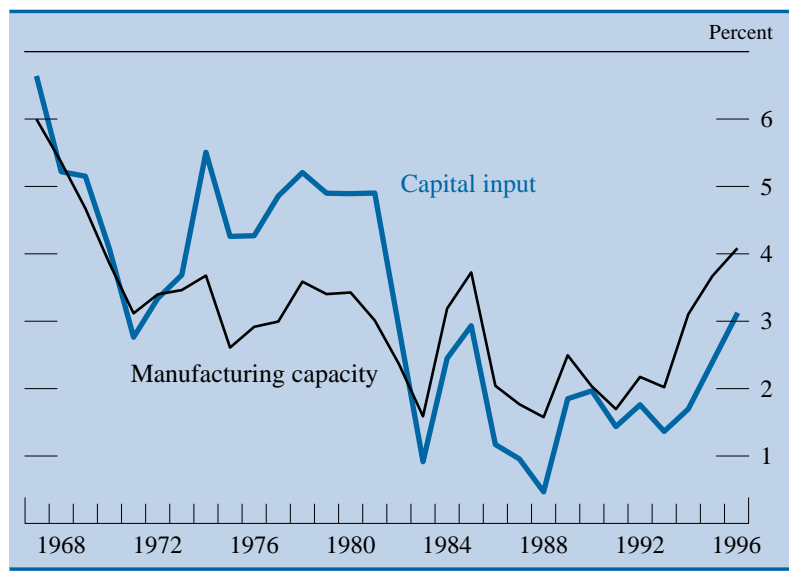

indicator. ${ }^{10}$ Interpolating between the final end-ofyear capacity indexes produces a continuous monthly time series.

The capital input measures, which reflect estimates of the service flow derived from the net stocks of productive tangible capital assets, were introduced in capacity estimation methods last year for the period from 1991 onward; as a result of the current revision the capital input measures are now incorporated in most manufacturing capacity series from 1977 onward. ${ }^{11}$ As a result, the annual changes in manufacturing capacity from 1977 onward are more strongly correlated with changes in capital input than are the annual changes in previous figures.

In general, the relationship between capacity and capital input is variable over time and across indus-

10. Specifically, the regressions fit the logarithm of the ratio of the capacity implied by the survey data to the alternative indicator by a low-order polynominal or piece-wise linear function of time. See Raddock, "A Revision to Industrial Production and Capacity Utilization, 1991-95," and "Recent Developments in Industrial Capacity and Utilization."

11. We estimate capital input for manufacturing industries in three steps. First, we prepare estimates of net capital stocks (by industry and asset type) from investment data using a perpetual inventory model; the methods used to derive the net stocks are described in Michael Mohr and Charles Gilbert, "Capital Stock Estimates for Manufacturing Industries: Methods and Data," Federal Reserve Board, Industrial Output Section, March 1996. Second, we develop annual estimates of the implicit rental prices for each asset type and use these estimates to create weights that describe the relative contribution made by each asset to the total input of capital. Finally, we create the annual estimates of capital input for each manufacturing capacity series by aggregating across the real net stocks by asset type using a chain-type quantity index that incorporates the weights created from the rental prices.

Since last year's annual revision, the basic elements used to create the capital input measures have been converted to use investment data expressed in chained 1992 dollars; otherwise, we use the same procedures to derive capital input. 
tries. For total manufacturing, capital input grew more rapidly than capacity in the late 1970s and more slowly after 1982 (chart 5). Capital expenditures on pollution abatement equipment, which grew rapidly in the late 1970s, are included in the net stocks used to derive the capital input measures and can cause the growth rates of capital input and capacity output to differ. Similarly, the bunching of permanent plant closings in some industries and the lengthening of the workweek of capital in others in the 1980s can lead to differences in the measures. In recent years, the relatively fast growth of capacity output generally represents continued gains in manufacturers' overall productivity (output per unit of combined inputs, including capital, labor, and materials) and an increase in their rate of capital investment.

In compiling this revision of manufacturing capacity, every effort has been made to achieve continuity with the unrevised estimates before 1977. The McGraw-Hill/DRI survey was the primary determinant of the level of utilization series in manufacturing from 1955 through the mid-1970s. Following previous practice, continuity is achieved by applying a level adjustment to series whose data source changed from the McGraw-Hill/DRI survey to the Census survey to maintain consistency with the historical levels based on the earlier survey. (The two surveys overlapped for fourteen years.) Generally, utilization rates from the Census survey, now the main source for manufacturing utilization rates, were lower, on average, than those of the discontinued McGraw-Hill/ DRI survey; thus Federal Reserve utilization rates for major industry totals and subtotals differ from those issued by the Census Bureau. 


\section{APPENDiX A: Summary TABLES PUBLISHED IN THE G.17 SUPPLEMENT, JANUARY 27, 1997}

A.1. Revised data for industrial production, capacity, and utilization for total industry, 1987-96

Seasonally adjusted data except as noted

\begin{tabular}{|c|c|c|c|c|c|c|c|c|c|c|c|c|c|c|c|c|c|}
\hline \multirow{2}{*}{ Year } & \multirow{2}{*}{ Jan. } & \multirow{2}{*}{ Feb. } & \multirow{2}{*}{ Mar. } & \multirow{2}{*}{ Apr. } & \multirow{2}{*}{ May } & \multirow{2}{*}{ June } & \multirow{2}{*}{ July } & \multirow{2}{*}{ Aug. } & \multirow{2}{*}{ Sept. } & \multirow{2}{*}{ Oct. } & \multirow{2}{*}{ Nov. } & \multirow{2}{*}{ Dec. } & \multicolumn{4}{|c|}{ Quarter } & \multirow{2}{*}{$\begin{array}{l}\text { Annua } \\
\text { avg. }{ }^{1}\end{array}$} \\
\hline & & & & & & & & & & & & & 1 & 2 & 3 & 4 & \\
\hline & \multicolumn{17}{|c|}{ Industrial production (percentage change) } \\
\hline 1987 & -.6 & 1.2 & .4 & .4 & .4 & .9 & 6 & .1 & -.1 & 1.3 & .3 & 6 & 4.3 & 6.7 & 5.6 & 6.9 & 4.6 \\
\hline 1988 & .1 & .3 & .0 & .6 & .1 & .0 & .7 & .5 & -.4 & .3 & .7 & .5 & 3.1 & 3.0 & 3.8 & 3.6 & 4.4 \\
\hline 1989 & .5 & -.8 & .9 & .3 & -.6 & -.2 & -1.0 & .4 & -.2 & -.5 & .4 & .5 & 3.8 & .5 & -4.4 & .0 & 1.8 \\
\hline 1990 & -.5 & .5 & .5 & -.6 & .4 & .0 & -.1 & .2 & .1 & -.5 & -1.3 & -.6 & 1.9 & .8 & .9 & -5.7 & -.2 \\
\hline 1991 & -.5 & -.8 & -.9 & .3 & .8 & 1.2 & .1 & .1 & .9 & -.1 & -.1 & -.6 & -8.2 & 1.3 & 6.3 & 1.1 & -2.0 \\
\hline 1992 & .0 & .7 & .8 & .7 & .4 & -.3 & .7 & -.4 & .5 & 8 & .6 & .1 & 1.1 & 6.7 & 2.2 & 5.6 & 3.2 \\
\hline 1993 & .4 & .5 & .1 & .3 & -.6 & .2 & .3 & -.2 & 1.0 & .3 & .5 & .7 & 3.7 & .8 & 1.7 & 5.8 & 3.4 \\
\hline 1994 & .3 & .5 & .7 & .4 & .6 & .5 & .5 & .0 & .1 & 6 & 6 & .9 & 6.2 & 6.7 & 4.4 & 5.6 & 5.0 \\
\hline 1995 & .3 & -.2 & .1 & -.3 & .1 & .2 & .0 & .8 & .4 & -.4 & .2 & .1 & 3.9 & -.7 & 3.2 & .8 & 3.3 \\
\hline \multirow[t]{2}{*}{1996} & -.4 & 1.3 & -.5 & .9 & .4 & .6 & .0 & .3 & .1 & .0 & .8 & .7 & 1.6 & 6.2 & 3.3 & 3.8 & 2.7 \\
\hline & & & & & & & & dustrial & product & n (inde & & & & & & & \\
\hline 1987 & 90.2 & 91.2 & 91.5 & 91.9 & 92.3 & 93.1 & 93.7 & 93.8 & 93.7 & 94.9 & 95.2 & 95.8 & 91.0 & 92.5 & 93.7 & 95.3 & 93.1 \\
\hline 1988 & 95.8 & 96.1 & 96.2 & 96.7 & 96.8 & 96.8 & 97.4 & 98.0 & 97.6 & 97.9 & 98.6 & 99.1 & 96.0 & 96.8 & 97.7 & 98.5 & 97.3 \\
\hline 1989 & 99.7 & 98.9 & 99.8 & 100.1 & 99.5 & 99.3 & 98.3 & 98.7 & 98.5 & 98.1 & 98.5 & 98.9 & 99.5 & 99.6 & 98.5 & 98.5 & 99.0 \\
\hline 1990 & 98.5 & 99.0 & 99.4 & 98.9 & 99.3 & 99.3 & 99.2 & 99.4 & 99.5 & 99.0 & 97.7 & 97.1 & 99.0 & 99.2 & 99.4 & 97.9 & 98.9 \\
\hline 1991 & 96.7 & 95.9 & 95.0 & 95.3 & 96.0 & 97.2 & 97.2 & 97.4 & 98.3 & 98.2 & 98.1 & 97.4 & 95.8 & 96.2 & 97.6 & 97.9 & 96.9 \\
\hline 1992 & 97.5 & 98.1 & 98.9 & 99.6 & 100.0 & 99.7 & 100.4 & 100.1 & 100.5 & 101.3 & 101.9 & 101.9 & 98.2 & 99.8 & 100.3 & 101.7 & 100.0 \\
\hline 1993 & 102.3 & 102.8 & 102.8 & 103.2 & 102.6 & 102.8 & 103.1 & 102.8 & 103.9 & 104.1 & 104.6 & 105.4 & 102.6 & 102.8 & 103.3 & 104.7 & 103.4 \\
\hline 1994 & 105.7 & 106.2 & 107.0 & 107.4 & 108.1 & 108.6 & 109.1 & 109.2 & 109.3 & 109.9 & 110.6 & 111.6 & 106.3 & 108.0 & 109.2 & 110.7 & 108.6 \\
\hline 1995 & 111.9 & 111.6 & 111.7 & 111.4 & 111.5 & 111.7 & 111.7 & 112.6 & 113.0 & 112.5 & 112.7 & 112.8 & 111.8 & 111.6 & 112.4 & 112.7 & 112.1 \\
\hline 1996 & 112.4 & 113.8 & 113.2 & 114.3 & 114.8 & 115.5 & 115.5 & 115.8 & 116.0 & 116.0 & 116.9 & 117.7 & 113.1 & 114.8 & 115.8 & 116.8 & 115.1 \\
\hline & & & & & & & & Cap & acity (in & lex) & & & & & & & \\
\hline 1987 & 113.9 & 114.0 & 114.1 & 114.3 & 114.4 & 114.5 & 114.6 & 114.7 & 114.8 & 115.0 & 115.1 & 115.2 & 114.0 & 114.4 & 114.7 & 115.1 & 114.6 \\
\hline 1988 & 115.3 & 115.5 & 115.6 & 115.7 & 115.8 & 115.9 & 116.0 & 116.2 & 116.3 & 116.4 & 116.5 & 116.7 & 115.5 & 115.8 & 116.2 & 116.5 & 116.0 \\
\hline 1989 & 116.8 & 117.0 & 117.2 & 117.4 & 117.6 & 117.8 & 118.0 & 118.2 & 118.4 & 118.6 & 118.8 & 119.0 & 117.0 & 117.6 & 118.2 & 118.8 & 117.9 \\
\hline 1990 & 119.2 & 119.3 & 119.5 & 119.7 & 119.9 & 120.0 & 120.2 & 120.4 & 120.6 & 120.8 & 121.0 & 121.2 & 119.3 & 119.9 & 120.4 & 121.0 & 120.1 \\
\hline 1991 & 121.4 & 121.5 & 121.7 & 121.9 & 122.0 & 122.2 & 122.4 & 122.5 & 122.7 & 122.8 & 123.0 & 123.2 & 121.5 & 122.0 & 122.5 & 123.0 & 122.3 \\
\hline 1992 & 123.3 & 123.6 & 123.8 & 124.0 & 124.2 & 124.4 & 124.6 & 124.7 & 124.9 & 125.1 & 125.3 & 125.5 & 123.6 & 124.2 & 124.7 & 125.3 & 124.4 \\
\hline 1993 & 125.7 & 125.8 & 126.0 & 126.2 & 126.4 & 126.6 & 126.7 & 126.9 & 127.1 & 127.3 & 127.5 & 127.7 & 125.8 & 126.4 & 126.9 & 127.5 & 126.7 \\
\hline 1994 & 128.0 & 128.3 & 128.6 & 128.9 & 129.2 & 129.5 & 129.8 & 130.1 & 130.5 & 130.8 & 131.1 & 131.4 & 128.3 & 129.2 & 130.1 & 131.1 & 129.7 \\
\hline 1995 & 131.8 & 132.1 & 132.5 & 132.8 & 133.2 & 133.6 & 134.0 & 134.3 & 134.7 & 135.1 & 135.5 & 135.9 & 132.1 & 133.2 & 134.3 & 135.5 & 133.8 \\
\hline 1996 & 136.3 & 136.7 & 137.1 & 137.5 & 137.9 & 138.4 & 138.8 & 139.2 & 139.6 & 140.0 & 140.5 & 140.9 & 136.7 & 137.9 & 139.2 & 140.5 & 138.6 \\
\hline & & & & & & & & Jtilizati & n (level & percent & & & & & & & \\
\hline 1987 & 79.1 & 80.0 & 80.2 & 80.5 & 80.7 & 81.3 & 81.8 & 81.7 & 81.6 & 82.6 & 82.7 & 83.1 & 79.8 & 80.8 & 81.7 & 82.8 & 81.3 \\
\hline 1988 & 83.1 & 83.3 & 83.2 & 83.6 & 83.6 & 83.5 & 84.0 & 84.3 & 84.0 & 84.1 & 84.6 & 85.0 & 83.2 & 83.6 & 84.1 & 84.6 & 83.9 \\
\hline 1989 & 85.3 & 84.5 & 85.1 & 85.2 & 84.6 & 84.3 & 83.3 & 83.5 & 83.2 & 82.7 & 82.9 & 83.2 & 85.0 & 84.7 & 83.3 & 82.9 & 84.0 \\
\hline 1990 & 82.6 & 82.9 & 83.2 & 82.6 & 82.8 & 82.7 & 82.5 & 82.5 & 82.5 & 81.9 & 80.7 & 80.1 & 82.9 & 82.7 & 82.5 & 80.9 & 82.3 \\
\hline 1991 & 79.6 & 78.9 & 78.1 & 78.2 & 78.7 & 79.5 & 79.5 & 79.5 & 80.1 & 79.9 & 79.7 & 79.1 & 78.9 & 78.8 & 79.7 & 79.6 & 79.2 \\
\hline 1992 & 79.0 & 79.4 & 79.9 & 80.4 & 80.6 & 80.2 & 80.6 & 80.2 & 80.5 & 81.0 & 81.3 & 81.2 & 79.5 & 80.4 & 80.4 & 81.2 & 80.4 \\
\hline 1993 & 81.4 & 81.7 & 81.6 & 81.7 & 81.2 & 81.2 & 81.3 & 81.0 & 81.7 & 81.8 & 82.1 & 82.5 & 81.6 & 81.4 & 81.3 & 82.1 & 81.6 \\
\hline 1994 & 82.6 & 82.8 & 83.2 & 83.3 & 83.7 & 83.9 & 84.1 & 83.9 & 83.7 & 84.1 & 84.4 & 84.9 & 82.9 & 83.6 & 83.9 & 84.4 & 83.7 \\
\hline 1995 & 84.9 & 84.5 & 84.3 & 83.9 & 83.7 & 83.6 & 83.4 & 83.8 & 83.9 & 83.3 & 83.2 & 83.0 & 84.6 & 83.7 & 83.7 & 83.2 & 83.8 \\
\hline 1996 & 82.4 & 83.2 & 82.6 & 83.1 & 83.2 & 83.5 & 83.2 & 83.2 & 83.1 & 82.8 & 83.2 & 83.5 & 82.8 & 83.3 & 83.2 & 83.2 & 83.1 \\
\hline
\end{tabular}

NoTE. Monthly figures show the percentage change from the previous month; quarterly figures show the change from the previous quarter at a compound annual rate of growth. Estimates from October 1996 through December 1996 are

1. Annual averages of industrial production are calculated from not seasonsubject to further revision in the upcoming monthly releases. Production and capacity indexes are expressed as percentages of output in 1992. 
A.2. Revised data for industrial production, capacity, and utilization for manufacturing industries, 1987-96 Seasonally adjusted data except as noted

\begin{tabular}{|c|c|c|c|c|c|c|c|c|c|c|c|c|c|c|c|c|c|}
\hline \multirow{2}{*}{ Year } & \multirow{2}{*}{ Jan. } & \multirow{2}{*}{ Feb. } & \multirow{2}{*}{ Mar. } & \multirow{2}{*}{ Apr. } & \multirow{2}{*}{ May } & \multirow{2}{*}{ June } & \multirow{2}{*}{ July } & \multirow{2}{*}{ Aug. } & \multirow{2}{*}{ Sept. } & \multirow{2}{*}{ Oct. } & \multirow{2}{*}{ Nov. } & \multirow{2}{*}{ Dec. } & \multicolumn{4}{|c|}{ Quarter } & \multirow{2}{*}{$\begin{array}{c}\text { Annua } \\
\text { avg. }\end{array}$} \\
\hline & & & & & & & & & & & & & 1 & 2 & 3 & 4 & \\
\hline & \multicolumn{17}{|c|}{ Industrial production (percentage change) } \\
\hline $\begin{array}{l}1987 \\
1988 \\
1989 \\
1990 \\
1991 \\
1992 \\
1993 \\
1994 \\
1995 \\
1996\end{array}$ & $\begin{array}{r}-.8 \\
-.2 \\
.9 \\
-.2 \\
-.9 \\
.2 \\
.8 \\
.1 \\
.4 \\
-.4\end{array}$ & $\begin{array}{r}1.6 \\
.4 \\
-1.2 \\
.9 \\
-.7 \\
.8 \\
.3 \\
.6 \\
-.4 \\
1.3\end{array}$ & $\begin{array}{r}.2 \\
-.1 \\
.8 \\
.3 \\
-1.1 \\
.9 \\
.1 \\
.9 \\
.1 \\
-.8\end{array}$ & $\begin{array}{r}.5 \\
1.0 \\
.1 \\
-.8 \\
.3 \\
.6 \\
.5 \\
.7 \\
-.3 \\
1.1\end{array}$ & $\begin{array}{r}.3 \\
-.1 \\
-.7 \\
.4 \\
.7 \\
.4 \\
-.5 \\
.7 \\
-.1 \\
.4\end{array}$ & $\begin{array}{r}1.0 \\
.0 \\
.0 \\
-.1 \\
1.4 \\
-.1 \\
.0 \\
.2 \\
.2 \\
.7\end{array}$ & $\begin{array}{r}.7 \\
.7 \\
-1.1 \\
.0 \\
.2 \\
.7 \\
.3 \\
.8 \\
-.1 \\
.5\end{array}$ & $\begin{array}{r}-.2 \\
.3 \\
.4 \\
.3 \\
.2 \\
-.3 \\
-.3 \\
.1 \\
.7 \\
.1\end{array}$ & $\begin{array}{r}.1 \\
.2 \\
-.3 \\
.0 \\
1.1 \\
.4 \\
1.1 \\
.2 \\
.7 \\
.2\end{array}$ & $\begin{array}{r}1.3 \\
.2 \\
-.6 \\
-.6 \\
-.1 \\
.7 \\
.2 \\
.7 \\
-.4 \\
.0\end{array}$ & $\begin{array}{r}.5 \\
1.0 \\
.4 \\
-1.3 \\
-.2 \\
.6 \\
.5 \\
.7 \\
-.1 \\
.6\end{array}$ & $\begin{array}{r}.6 \\
.6 \\
.1 \\
-.6 \\
-.5 \\
-.1 \\
.8 \\
.9 \\
.1 \\
1.0\end{array}$ & $\begin{array}{r}5.0 \\
2.4 \\
4.3 \\
2.9 \\
-9.7 \\
2.3 \\
4.5 \\
6.3 \\
4.2 \\
1.1\end{array}$ & $\begin{array}{r}7.0 \\
4.1 \\
-.7 \\
-.1 \\
1.2 \\
7.3 \\
1.4 \\
8.1 \\
-1.4 \\
6.3\end{array}$ & $\begin{array}{r}5.5 \\
3.7 \\
-4.5 \\
.8 \\
7.8 \\
2.8 \\
1.2 \\
5.0 \\
2.6 \\
5.0\end{array}$ & $\begin{array}{r}7.6 \\
5.2 \\
-1.4 \\
-6.3 \\
1.7 \\
5.1 \\
6.2 \\
6.7 \\
1.0 \\
3.7\end{array}$ & $\begin{array}{r}5.3 \\
4.7 \\
1.9 \\
-.5 \\
-2.4 \\
4.0 \\
3.7 \\
5.5 \\
3.5 \\
2.7\end{array}$ \\
\hline 1996 & \multicolumn{17}{|c|}{ Industrial production (index) } \\
\hline $\begin{array}{l}1987 \\
1988 \\
1989 \\
1990 \\
1991 \\
1992 \\
1993 \\
1994 \\
1995 \\
1996\end{array}$ & $\begin{array}{r}89.6 \\
95.4 \\
100.3 \\
98.1 \\
95.8 \\
97.2 \\
102.6 \\
106.0 \\
113.3 \\
113.4\end{array}$ & $\begin{array}{r}91.0 \\
95.8 \\
99.1 \\
99.0 \\
95.1 \\
98.0 \\
102.9 \\
106.6 \\
112.9 \\
114.8\end{array}$ & $\begin{array}{r}91.2 \\
95.7 \\
99.9 \\
99.3 \\
94.1 \\
98.9 \\
103.0 \\
107.5 \\
113.1 \\
113.9\end{array}$ & $\begin{array}{r}91.6 \\
96.7 \\
100.0 \\
98.6 \\
94.4 \\
99.5 \\
103.6 \\
108.2 \\
112.7 \\
115.2\end{array}$ & $\begin{array}{r}91.9 \\
96.6 \\
99.4 \\
99.0 \\
95.0 \\
100.0 \\
103.0 \\
109.0 \\
112.6 \\
115.7\end{array}$ & $\begin{array}{r}92.8 \\
96.6 \\
99.4 \\
98.9 \\
96.3 \\
99.9 \\
103.0 \\
109.2 \\
112.9 \\
116.4\end{array}$ & $\begin{array}{r}93.4 \\
97.2 \\
98.3 \\
98.8 \\
96.6 \\
100.5 \\
103.4 \\
110.0 \\
112.7 \\
117.0\end{array}$ & $\begin{array}{r}93.3 \\
97.5 \\
98.7 \\
99.1 \\
96.8 \\
100.2 \\
103.0 \\
110.1 \\
113.4 \\
117.2\end{array}$ & $\begin{array}{r}93.4 \\
97.7 \\
98.4 \\
99.1 \\
97.8 \\
100.6 \\
104.2 \\
110.3 \\
114.2 \\
117.4\end{array}$ & $\begin{array}{r}94.6 \\
97.9 \\
97.9 \\
98.5 \\
97.8 \\
101.4 \\
104.4 \\
111.1 \\
113.8 \\
117.4\end{array}$ & $\begin{array}{r}95.0 \\
98.9 \\
98.2 \\
97.2 \\
97.6 \\
102.0 \\
105.0 \\
111.9 \\
113.6 \\
118.1\end{array}$ & $\begin{array}{r}95.6 \\
99.4 \\
98.3 \\
96.6 \\
97.1 \\
101.8 \\
105.9 \\
112.9 \\
113.8 \\
119.3\end{array}$ & $\begin{array}{r}90.6 \\
95.7 \\
99.8 \\
98.8 \\
95.0 \\
98.0 \\
102.9 \\
106.7 \\
113.1 \\
114.0\end{array}$ & $\begin{array}{r}92.1 \\
96.6 \\
99.6 \\
98.8 \\
95.2 \\
99.8 \\
103.2 \\
108.8 \\
112.7 \\
115.8\end{array}$ & $\begin{array}{r}93.4 \\
97.5 \\
98.5 \\
99.0 \\
97.0 \\
100.5 \\
103.5 \\
110.2 \\
113.4 \\
117.2\end{array}$ & $\begin{array}{r}95.1 \\
98.7 \\
98.1 \\
97.4 \\
97.5 \\
101.7 \\
105.1 \\
111.9 \\
113.7 \\
118.3\end{array}$ & $\begin{array}{r}92.8 \\
97.1 \\
99.0 \\
98.5 \\
96.2 \\
100.0 \\
103.7 \\
109.4 \\
113.2 \\
116.3\end{array}$ \\
\hline 1996 & \multicolumn{17}{|c|}{ Capacity (index) } \\
\hline $\begin{array}{l}1987 \\
1988 \\
1989 \\
1990 \\
1991 \\
1992 \\
1993 \\
1994 \\
1995 \\
1996\end{array}$ & $\begin{array}{l}113.2 \\
115.1 \\
117.0 \\
119.9 \\
122.4 \\
124.5 \\
127.2 \\
129.8 \\
134.0 \\
139.1\end{array}$ & $\begin{array}{l}113.4 \\
115.3 \\
117.3 \\
120.1 \\
122.6 \\
124.7 \\
127.4 \\
130.1 \\
134.4 \\
139.6\end{array}$ & $\begin{array}{l}113.6 \\
115.4 \\
117.5 \\
120.3 \\
122.7 \\
125.0 \\
127.6 \\
130.5 \\
134.8 \\
140.1\end{array}$ & $\begin{array}{l}113.8 \\
115.5 \\
117.8 \\
120.5 \\
122.9 \\
125.2 \\
127.8 \\
130.8 \\
135.2 \\
140.5\end{array}$ & $\begin{array}{l}113.9 \\
115.7 \\
118.0 \\
120.7 \\
123.1 \\
125.4 \\
128.0 \\
131.2 \\
135.6 \\
141.0\end{array}$ & $\begin{array}{l}114.1 \\
115.8 \\
118.3 \\
120.9 \\
123.3 \\
125.7 \\
128.2 \\
131.5 \\
136.0 \\
141.5\end{array}$ & $\begin{array}{l}114.2 \\
116.0 \\
118.5 \\
121.1 \\
123.5 \\
125.9 \\
128.4 \\
131.9 \\
136.5 \\
142.0\end{array}$ & $\begin{array}{l}114.4 \\
116.1 \\
118.7 \\
121.3 \\
123.6 \\
126.1 \\
128.6 \\
132.2 \\
136.9 \\
142.5\end{array}$ & $\begin{array}{l}114.6 \\
116.3 \\
119.0 \\
121.5 \\
123.8 \\
126.3 \\
128.9 \\
132.6 \\
137.3 \\
142.9\end{array}$ & $\begin{array}{l}114.7 \\
116.5 \\
119.2 \\
121.7 \\
124.0 \\
126.5 \\
129.1 \\
132.9 \\
137.8 \\
143.4\end{array}$ & $\begin{array}{l}114.9 \\
116.6 \\
119.5 \\
121.9 \\
124.2 \\
126.8 \\
129.3 \\
133.3 \\
138.2 \\
143.9\end{array}$ & $\begin{array}{l}115.0 \\
116.8 \\
119.7 \\
122.2 \\
124.3 \\
127.0 \\
129.5 \\
133.6 \\
138.7 \\
144.4\end{array}$ & $\begin{array}{l}113.4 \\
115.3 \\
117.3 \\
120.1 \\
122.6 \\
124.7 \\
127.4 \\
130.1 \\
134.4 \\
139.6\end{array}$ & $\begin{array}{l}113.9 \\
115.7 \\
118.0 \\
120.7 \\
123.1 \\
125.4 \\
128.0 \\
131.2 \\
135.6 \\
141.0\end{array}$ & $\begin{array}{l}114.4 \\
116.1 \\
118.7 \\
121.3 \\
123.6 \\
126.1 \\
128.7 \\
132.2 \\
136.9 \\
142.5\end{array}$ & $\begin{array}{l}114.9 \\
116.6 \\
119.5 \\
121.9 \\
124.1 \\
126.8 \\
129.3 \\
133.3 \\
138.2 \\
143.9\end{array}$ & $\begin{array}{l}114.1 \\
115.9 \\
118.4 \\
121.0 \\
123.4 \\
125.8 \\
128.3 \\
131.7 \\
136.3 \\
141.7\end{array}$ \\
\hline 1996 & \multicolumn{17}{|c|}{ Utilization (level, percent) } \\
\hline 1987 & 79.1 & 80.2 & 80.3 & 80.6 & 80.7 & 81.4 & 81.8 & 81.5 & 81.5 & 82.5 & 82.8 & 83.1 & 79.9 & 80.9 & 81.6 & 82.8 & 81.3 \\
\hline 1988 & 82.9 & 83.1 & 82.9 & 83.7 & 83.5 & 83.4 & 83.8 & 84.0 & 84.0 & 84.1 & 84.8 & 85.1 & 83.0 & 83.5 & 83.9 & 84.7 & 83.8 \\
\hline 1989 & 85.7 & 84.5 & 85.0 & 84.9 & 84.2 & 84.1 & 83.0 & 83.1 & 82.7 & 82.1 & 82.2 & 82.2 & 85.1 & 84.4 & 82.9 & 82.1 & 83.6 \\
\hline 1990 & 81.8 & 82.4 & 82.6 & 81.8 & 82.0 & 81.8 & 81.6 & 81.7 & 81.5 & 80.9 & 79.7 & 79.1 & 82.3 & 81.9 & 81.6 & 79.9 & 81.4 \\
\hline 1991 & 78.2 & 77.6 & 76.6 & 76.8 & 77.2 & 78.1 & 78.2 & 78.3 & 79.0 & 78.9 & 78.6 & 78.1 & 77.5 & 77.4 & 78.5 & 78.5 & 78.0 \\
\hline 1992 & 78.1 & 78.6 & 79.1 & 79.5 & 79.7 & 79.5 & 79.9 & 79.5 & 79.7 & 80.1 & 80.4 & 80.2 & 78.6 & 79.5 & 79.7 & 80.2 & 79.5 \\
\hline 1993 & 80.7 & 80.8 & 80.7 & 81.0 & 80.5 & 80.4 & 80.5 & 80.1 & 80.9 & 80.9 & 81.2 & 81.7 & 80.7 & 80.6 & 80.5 & 81.3 & 80.8 \\
\hline 1994 & 81.6 & 81.9 & 82.4 & 82.7 & 83.1 & 83.0 & 83.4 & 83.3 & 83.2 & 83.6 & 84.0 & 84.5 & 82.0 & 83.0 & 83.3 & 84.0 & 83.1 \\
\hline 1995 & 84.6 & 84.0 & 83.9 & 83.4 & 83.0 & 83.0 & 82.6 & 82.9 & 83.2 & 82.6 & 82.2 & 82.0 & 84.2 & 83.1 & 82.9 & 82.3 & 83.1 \\
\hline 1996 & 81.5 & 82.2 & 81.3 & 82.0 & 82.0 & 82.3 & 82.4 & 82.3 & 82.1 & 81.8 & 82.1 & 82.6 & 81.7 & 82.1 & 82.3 & 82.2 & 82.1 \\
\hline
\end{tabular}

Note. See notes to table A.1. 
A.3. Revised growth rates of industrial production, by market group, 1977-96

\begin{tabular}{|c|c|c|c|c|c|c|c|c|}
\hline \multirow[t]{2}{*}{ Series } & \multicolumn{4}{|c|}{$\begin{array}{l}\text { Revised growth rate } \\
\text { (percent) }\end{array}$} & \multicolumn{4}{|c|}{$\begin{array}{l}\text { Difference between revised } \\
\text { and earlier growth rates } \\
\text { (percentage points) }\end{array}$} \\
\hline & $1977-82$ & $1982-87$ & $1987-92$ & $1992-96$ & $1977-82$ & $1982-87$ & 1987-92 & 1992-96 \\
\hline Total index & .5 & 4.0 & 1.4 & 3.6 & -.5 & -.1 & -.1 & -.4 \\
\hline Products, total & 1.2 & 4.1 & 1.0 & 2.9 & -.7 & -.6 & -.2 & -.6 \\
\hline Final products & 1.6 & 3.6 & 1.4 & 3.0 & -.9 & -.8 & -.3 & -.6 \\
\hline Consumer goods & -.2 & 3.5 & 1.3 & 2.5 & .0 & .1 & .1 & .1 \\
\hline Durable ....... & -4.3 & 8.5 & 1.3 & 6.0 & .0 & .7 & .7 & 1.1 \\
\hline Automotive products .. & -7.5 & 11.2 & -.1 & 5.9 & -.2 & -.5 & -.3 & -1.0 \\
\hline Other durable goods ... & -2.2 & 6.7 & 2.3 & 6.0 & .1 & 1.6 & 1.4 & 2.8 \\
\hline Nondurable .......... & 1.1 & 2.1 & 1.3 & 1.6 & -.1 & -.1 & .0 & -.2 \\
\hline Non-energy products & 1.5 & 2.2 & 1.3 & 1.4 & -.1 & -.1 & .0 & -.2 \\
\hline Energy products ...... & -.6 & 1.7 & 1.5 & 2.7 & -.1 & -.1 & -.1 & -.2 \\
\hline Equipment, total & 3.9 & 3.6 & 1.5 & 4.0 & -1.7 & -1.7 & -.8 & -1.8 \\
\hline Business .... & 2.6 & 3.8 & 3.3 & 6.1 & -2.5 & -2.7 & -1.0 & -2.0 \\
\hline Industrial & -2.6 & -1.7 & 1.0 & 6.1 & .0 & .0 & -.2 & 1.0 \\
\hline Information processing and related & 14.5 & 9.1 & 4.8 & 9.4 & -3.7 & -5.3 & -1.8 & -4.5 \\
\hline Transit $\ldots \ldots \ldots \ldots \ldots \ldots \ldots \ldots$ & -1.2 & 4.0 & 5.8 & .0 & -.4 & -.6 & -.5 & .1 \\
\hline Other .. & -2.4 & 3.2 & .3 & 3.8 & -.1 & -.1 & -.3 & -.7 \\
\hline Defense and space $\ldots$ & 6.0 & 10.1 & -3.2 & -6.3 & .0 & 1.3 & .1 & .5 \\
\hline Intermediate products & .0 & 5.9 & -.1 & 2.3 & .0 & .0 & .0 & -.5 \\
\hline Construction supplies & -2.7 & 6.7 & -.9 & 4.0 & -.1 & .0 & .1 & -.3 \\
\hline Business supplies ....... & 2.1 & 5.3 & .3 & 1.2 & -.1 & .0 & -.1 & -.6 \\
\hline Materials . & -.5 & 3.8 & 2.0 & 4.7 & .0 & .5 & .2 & .0 \\
\hline Durable & -.6 & 6.9 & 2.7 & 7.6 & -.1 & 6 & .3 & .2 \\
\hline Nondurable....$\ldots \ldots \ldots$ & -1.1 & 4.0 & 1.9 & 1.5 & .0 & .0 & .0 & -.5 \\
\hline Energy $\ldots \ldots \ldots \ldots \ldots \ldots \ldots \ldots \ldots \ldots \ldots \ldots \ldots$ & -.3 & -.1 & .8 & 1.0 & -.2 & .1 & .0 & .0 \\
\hline \multicolumn{9}{|l|}{$\begin{array}{l}\text { Aggregates, excluding computer } \\
\text { and office equipment }\end{array}$} \\
\hline Total index ......... & -.1 & 3.6 & 1.3 & 3.1 & .0 & .3 & .1 & -.1 \\
\hline Business equipment ..... & -.2 & 1.6 & 2.8 & 3.7 & -.2 & -.1 & -.1 & -.2 \\
\hline
\end{tabular}

NoTE. Growth rates are calculated as the average annual percentage change from the first to the last year indicated. 
A.4. Revised growth rates of industrial production, by industry group, 1977-96

\begin{tabular}{|c|c|c|c|c|c|c|c|c|c|}
\hline \multirow[t]{2}{*}{ Series } & \multirow{2}{*}{$\begin{array}{l}\text { SIC } \\
\operatorname{code}^{1}\end{array}$} & \multicolumn{4}{|c|}{$\begin{array}{l}\text { Revised growth rate } \\
\text { (percent) }\end{array}$} & \multicolumn{4}{|c|}{$\begin{array}{l}\text { Difference between revised } \\
\text { and earlier growth rates } \\
\text { (percentage points) }\end{array}$} \\
\hline & & $1977-82$ & $1982-87$ & $1987-92$ & $1992-96$ & $1977-82$ & $1982-87$ & 1987-92 & 1992-96 \\
\hline Total index & $\ldots$ & .5 & 4.0 & 1.4 & 3.6 & -.5 & -.1 & -.1 & -.4 \\
\hline Manufacturing & $\ldots$ & .3 & 5.2 & 1.5 & 3.9 & -.6 & -.3 & -.1 & -.4 \\
\hline Primary processing ... & $\ldots$ & -2.7 & 4.7 & 1.0 & 2.9 & -.1 & .0 & .0 & -.3 \\
\hline Advanced processing & & 1.9 & 5.4 & 1.8 & 4.3 & -.8 & -.5 & -.1 & -.5 \\
\hline Durable manufacturing & . & .0 & 6.2 & 1.7 & 5.9 & -1.1 & -.4 & -.1 & -.5 \\
\hline Lumber and products & 24 & -4.0 & 8.3 & -1.0 & 2.3 & .0 & .1 & .0 & -.8 \\
\hline Furniture and fixtures & 25 & -.1 & 6.2 & -.2 & 2.2 & .0 & .0 & .0 & -.7 \\
\hline Stone, clay, and glass products & 32 & -3.1 & 4.5 & -.9 & 2.7 & -.1 & .0 & .0 & .0 \\
\hline Primary metals & 33 & -7.5 & 4.0 & .5 & 4.0 & -.2 & .2 & .1 & -.1 \\
\hline Iron and steel & 331,2 & -10.2 & 3.5 & .9 & 3.9 & -.3 & .5 & .0 & -.4 \\
\hline Raw steel & $331 \mathrm{pt}$ & -9.8 & 3.5 & .2 & 2.9 & .0 & .0 & .0 & .0 \\
\hline Nonferrous metals & $333-6,9$ & -2.8 & 4.6 & -.2 & 4.1 & .3 & .0 & .2 & .2 \\
\hline Fabricated metal products & 34 & -2.1 & 3.7 & -.4 & 4.4 & .0 & .0 & -.2 & .1 \\
\hline Industrial machinery and equipment & 35 & 3.1 & 5.5 & 3.1 & 11.8 & -4.2 & -3.9 & -1.3 & -1.6 \\
\hline Computer and office equipment .. & 357 & 33.4 & 23.9 & 10.0 & 31.3 & -1.6 & -4.5 & -1.6 & -.9 \\
\hline Electrical machinery...$\ldots \ldots \ldots$ & 36 & 6.3 & 7.9 & 5.7 & 13.0 & .9 & 2.3 & 1.4 & 1.8 \\
\hline $\begin{array}{c}\text { Semiconductors and related } \\
\text { components } \ldots \ldots \ldots . .\end{array}$ & $3672-9$ & 23.1 & 15.8 & 14.6 & 26.7 & 6.9 & 9.5 & 5.2 & 7.4 \\
\hline Transportation equipment ... & 37 & -2.6 & 8.8 & .8 & 1.4 & -.1 & -.3 & -.1 & -.7 \\
\hline Motor vehicles and parts & 371 & -9.2 & 10.8 & 1.0 & 6.0 & -.1 & -.4 & -.4 & -1.1 \\
\hline Autos and light trucks & $371 \mathrm{pt}$ & -8.4 & 12.6 & .3 & 5.6 & -.2 & -.1 & -.1 & -.7 \\
\hline Aerospace and miscellaneous & & & & & & & & & \\
\hline transportation equipment & $372-6$ & 4.2 & 7.4 & .5 & -3.8 & .0 & -.1 & .1 & .1 \\
\hline Instruments $\ldots \ldots \ldots \ldots \ldots \ldots \ldots$ & 38 & 4.9 & 4.2 & 1.3 & .7 & .0 & .1 & .1 & -.8 \\
\hline Miscellaneous manufactures & 39 & -1.6 & 1.8 & 1.3 & 3.0 & .0 & .1 & .0 & -.7 \\
\hline Nondurable manufacturing & & .5 & 3.9 & 1.3 & 1.5 & -.1 & -.1 & .0 & -.3 \\
\hline Foods $\ldots \ldots \ldots$ & 20 & 2.0 & 2.6 & 1.3 & 1.5 & -.1 & -.1 & .0 & -.5 \\
\hline Tobacco products & 21 & .6 & -.3 & -.9 & 1.4 & .0 & .0 & -.1 & 2.6 \\
\hline Textile mill products ... & 22 & -1.9 & 3.7 & .8 & 1.7 & .0 & .0 & .0 & .5 \\
\hline Apparel products ............ & 23 & -.3 & 1.8 & -1.1 & -.4 & .0 & -.3 & .0 & .9 \\
\hline Paper and products ........ & 26 & 1.2 & 4.1 & 1.9 & 1.9 & .2 & .0 & .0 & .1 \\
\hline Printing and publishing . & 27 & 3.2 & 5.7 & -.5 & -.3 & .0 & -.1 & -.1 & -.3 \\
\hline Chemicals and products & 28 & -.4 & 4.1 & 2.8 & 2.1 & .0 & .0 & .1 & -1.0 \\
\hline Petroleum products .... & 29 & -3.1 & 2.3 & .6 & 1.6 & .0 & .0 & .1 & -.3 \\
\hline Rubber and plastic products & 30 & .3 & 8.7 & 3.1 & 4.8 & -.1 & .0 & .0 & -.3 \\
\hline Leather and products ............. & 31 & -4.1 & -7.2 & -2.3 & -5.3 & .0 & .0 & .0 & -1.3 \\
\hline Mining & & 1.5 & -1.7 & -.3 & .8 & .0 & .1 & -.1 & .2 \\
\hline Metal mining & 10 & -2.2 & 2.5 & 10.1 & .4 & .9 & -.3 & -.3 & .1 \\
\hline Coal mining & 12 & 3.7 & 1.8 & 1.6 & 1.4 & .0 & .0 & .0 & -.1 \\
\hline Oil and gas extraction & 13 & 1.5 & -2.8 & -1.5 & .1 & -.3 & -.2 & -.1 & .2 \\
\hline Stone and earth minerals & 14 & -4.6 & 5.1 & -.2 & 4.3 & .0 & .3 & .0 & .3 \\
\hline Utilities .. & & .1 & 1.7 & 2.3 & 3.0 & -.3 & -.1 & .0 & -.1 \\
\hline Electric & $491,493 \mathrm{pt}$ & 1.6 & 3.1 & 2.3 & 3.0 & .0 & .0 & .0 & .0 \\
\hline Gas .... & $492,493 \mathrm{pt}$ & -3.2 & -2.8 & 2.4 & 2.7 & -.6 & .3 & -.1 & -.4 \\
\hline $\begin{array}{l}\text { Aggregate, excluding computer } \\
\text { and office equipment }\end{array}$ & & & & & & & & & \\
\hline Manufacturing ........ & $\ldots$ & -.4 & 4.7 & 1.3 & 3.3 & -.1 & .2 & .1 & -.2 \\
\hline
\end{tabular}

NotE. Growth rates are calculated as the average annual percentage change from the first to the last year indicated.

Primary-processing manufacturing includes textile mill products, paper and products, industrial chemicals, synthetic materials, and fertilizers, petroleum products, rubber and plastics products, lumber and products, primary metals, fabricated metals, and stone, clay, and glass products. Advanced-processing manufacturing includes foods, tobacco products, apparel products, printing and publishing, chemical products and other agricultural chemicals, leather and

products, furniture and fixtures, industrial and commercial machinery and computer equipment, electrical machinery, transportation equipment, instruments, and miscellaneous manufactures.

1. Standard Industrial Classification; see Executive Office of the President, Office of Management and Budget, Standard Industrial Classification Manual, 1987 (U.S. Government Printing Office, 1987).

pt Part of classification. 
A.5. Revised growth rates of industrial production, by major market group, 1992-96

\begin{tabular}{|c|c|c|c|c|c|c|c|c|c|c|}
\hline \multirow[t]{2}{*}{ Market group } & \multicolumn{5}{|c|}{$\begin{array}{l}\text { Revised growth rate } \\
\text { (percent) }\end{array}$} & \multicolumn{5}{|c|}{$\begin{array}{l}\text { Difference between revised } \\
\text { and earlier growth rates } \\
\text { (percentage points) }\end{array}$} \\
\hline & 1992 & 1993 & 1994 & 1995 & 1996 & 1992 & 1993 & 1994 & 1995 & 1996 \\
\hline Total index & 3.9 & 3.0 & 5.7 & 1.8 & 3.7 & -.1 & -.2 & -.9 & .2 & -.8 \\
\hline Products, total & 3.9 & 1.9 & 4.3 & 1.1 & 3.7 & -.2 & -.6 & -1.3 & .1 & -.9 \\
\hline Final products & 4.0 & 2.0 & 4.3 & 1.4 & 3.9 & -.3 & -.6 & -1.1 & .0 & -1.3 \\
\hline Consumer goods & 3.7 & 2.2 & 3.9 & .7 & 2.1 & .3 & .3 & -.1 & .2 & .1 \\
\hline Durable ....... & 7.4 & 10.3 & 6.6 & 1.1 & 2.7 & 6 & -.3 & .5 & 2.0 & 2.2 \\
\hline Automotive products & 11.7 & 11.6 & 5.7 & -.9 & 1.0 & .3 & -2.8 & -1.6 & .3 & -1.0 \\
\hline Other durable goods & 4.2 & 9.4 & 7.2 & 2.5 & 3.9 & 1.1 & 2.2 & 2.3 & 3.2 & 4.8 \\
\hline Nondurable .......... & 2.7 & .1 & 3.2 & .7 & 2.0 & .2 & .3 & -.3 & -.3 & -.5 \\
\hline Non-energy products & 2.8 & -.4 & 4.4 & -.3 & 2.4 & .2 & .2 & -.3 & -.5 & -.2 \\
\hline Energy products ...... & 2.5 & 3.4 & -4.0 & 6.6 & -.4 & .0 & .9 & .0 & .0 & -1.7 \\
\hline Equipment, total & 4.6 & 1.5 & 4.9 & 2.4 & 6.9 & -1.1 & -2.0 & -2.6 & -.1 & -3.0 \\
\hline Business ..... & 6.8 & 3.4 & 8.1 & 4.6 & 8.0 & -1.4 & -2.5 & -3.3 & .1 & -3.0 \\
\hline Industrial & 3.7 & 6.8 & 8.9 & 7.3 & -.2 & -.7 & .9 & .3 & 3.8 & -.1 \\
\hline Information processing and related & 13.2 & 2.0 & 11.5 & 12.2 & 11.2 & -1.7 & -5.5 & -6.3 & -1.8 & -6.2 \\
\hline Transit $\ldots \ldots \ldots \ldots \ldots \ldots \ldots \ldots$ & .8 & -2.1 & 1.1 & -13.4 & 21.6 & .3 & -2.9 & -1.4 & .8 & 5.3 \\
\hline Other .. & 3.4 & 9.6 & 5.4 & -.8 & 2.4 & -1.3 & -.4 & -2.5 & 2.8 & -1.2 \\
\hline Defense and space & -5.8 & -6.5 & -8.0 & -8.2 & -.9 & .0 & .5 & 2.3 & .9 & -2.1 \\
\hline Intermediate products & 3.3 & 1.8 & 4.3 & .1 & 3.1 & .1 & -.8 & -2.0 & .2 & .3 \\
\hline Construction supplies & 3.7 & 5.8 & 6.6 & -.8 & 5.9 & -.3 & -.2 & -1.5 & -.4 & .6 \\
\hline Business supplies .... & 3.1 & -.5 & 3.0 & .7 & 1.3 & .4 & -1.1 & -2.3 & .7 & .2 \\
\hline Materials . & 3.9 & 4.6 & 7.9 & 2.9 & 3.7 & .2 & .4 & -.2 & .5 & -.7 \\
\hline Durable .. & 6.5 & 8.2 & 10.9 & 5.7 & 5.1 & .2 & 1.0 & -.3 & .4 & -.3 \\
\hline Nondurable & 2.4 & 1.7 & 5.9 & -2.3 & 1.7 & .1 & -.6 & -1.0 & 4 & -1.4 \\
\hline Energy $\ldots .$. & .0 & -.6 & 2.1 & .9 & 1.9 & .0 & -.2 & .3 & .8 & -1.2 \\
\hline \multicolumn{11}{|l|}{$\begin{array}{l}\text { Aggregates, excluding computer } \\
\text { and office equipment }\end{array}$} \\
\hline Total index ........ & 3.5 & 2.7 & 5.3 & 1.1 & 2.9 & .2 & -.1 & -.8 & .5 & -.2 \\
\hline Business equipment . & 4.7 & 2.4 & 6.2 & 1.1 & 4.4 & -.1 & -1.1 & -2.4 & 2.3 & .7 \\
\hline
\end{tabular}

Note. Growth rates are calculated as the percentage change in the seasonally adjusted index from the fourth quarter of the previous year to the fourth quarter of the year specified. 
A.6. Revised rates of growth in industrial production, by major industry group, 1992-96

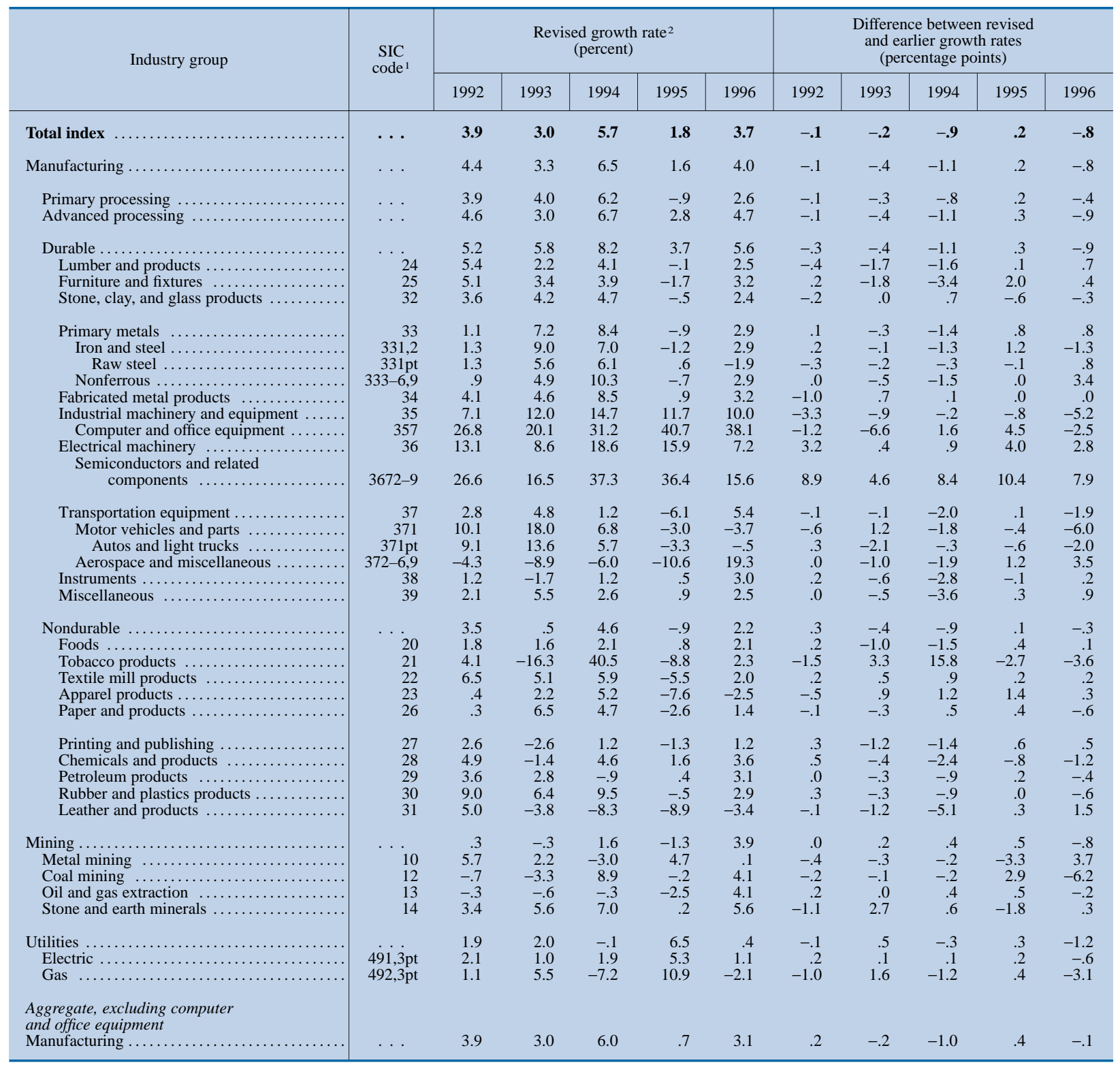

NotE. See notes to table A.4. Growth rates are calculated as the percentage change in the seasonally adjusted index from the fourth quarter of the previous

1. Standard Industrial Classification, see table A.4, note 1 . year to the fourth quarter of the year specified. 
A.7. Revised and earlier capacity utilization rates, by major industry group, 1967-96

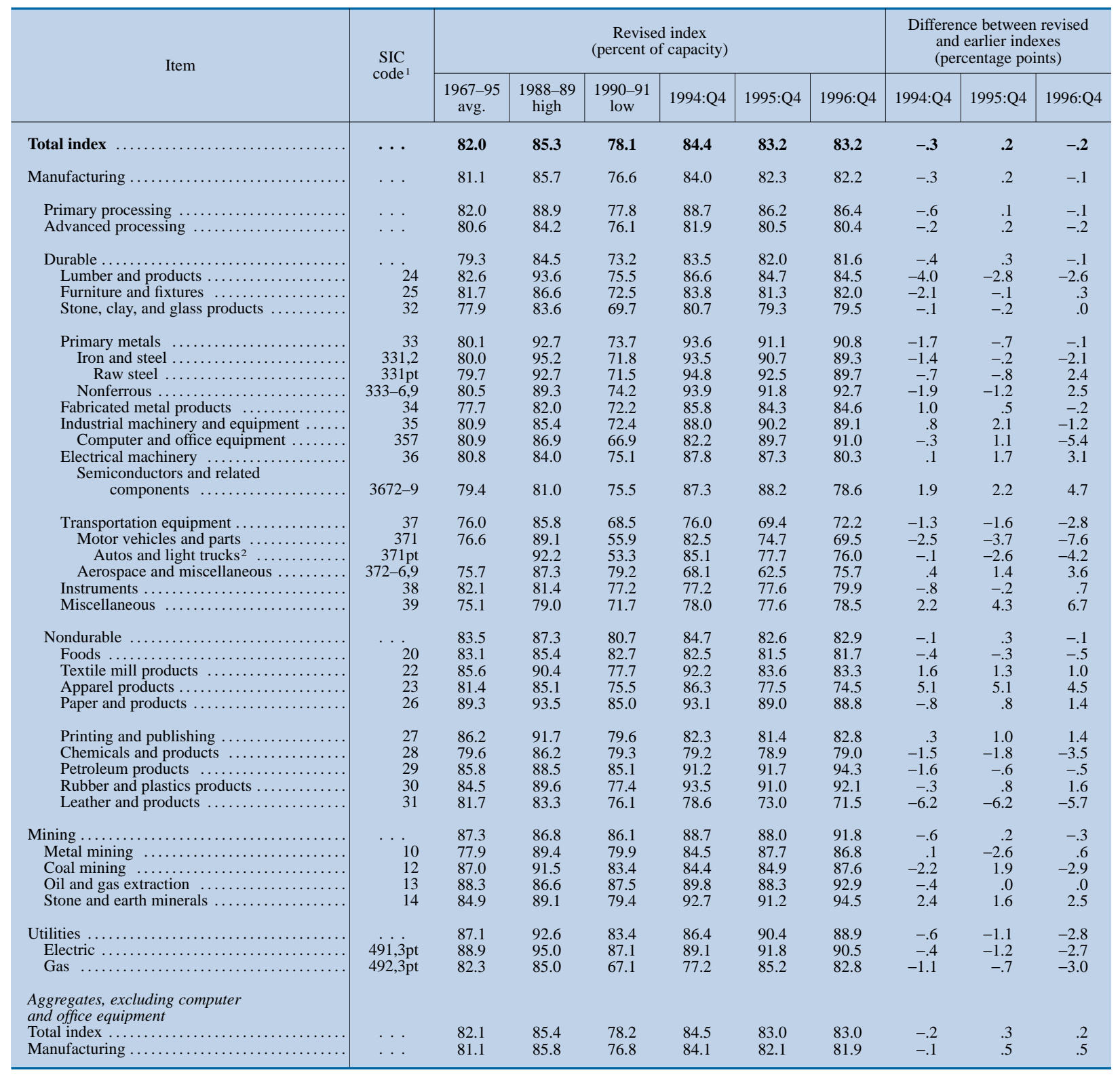

Note. The "high" columns refer to periods in which utilization generally 1. Standard Industrial Classification; see table A.4, note 1. peaked; the "low" columns refer to recession years in which utilization generally bottomed out. The monthly highs and lows are specific to each series, and 2. Series begins in 1977. all did not occur in the same month. 
A.8. Revised growth rates of capacity, by major industry group, 1992-96

\begin{tabular}{|c|c|c|c|c|c|c|c|c|c|c|c|}
\hline \multirow[t]{2}{*}{ Industry group } & \multirow[t]{2}{*}{$\begin{array}{l}\text { SIC } \\
\text { code }\end{array}$} & \multicolumn{5}{|c|}{$\begin{array}{l}\text { Revised growth rate } \\
\text { (percent) }\end{array}$} & \multicolumn{5}{|c|}{$\begin{array}{l}\text { Difference between revised } \\
\text { and earlier growth rates } \\
\text { (percentage points) }\end{array}$} \\
\hline & & 1992 & 1993 & 1994 & 1995 & 1996 & 1992 & 1993 & 1994 & 1995 & 1996 \\
\hline Total index & $\cdots$ & 1.9 & 1.8 & 2.8 & 3.3 & 3.7 & -.2 & -.4 & -.3 & -.4 & -.3 \\
\hline Manufacturing . & $\ldots$ & 2.1 & 2.0 & 3.1 & 3.7 & 4.1 & -.3 & -.5 & -.4 & -.5 & -.3 \\
\hline Primary processing & $\ldots$ & 1.0 & 1.2 & 2.0 & 2.1 & 2.4 & -.3 & -.3 & -.2 & -.5 & -.1 \\
\hline Advanced processing & $\ldots$ & 2.6 & 2.4 & 3.7 & 4.6 & 4.9 & -.3 & -.6 & -.4 & -.3 & -.4 \\
\hline Durable & & 2.0 & 2.5 & 4.1 & 5.5 & 6.1 & -.5 & -.6 & -.5 & -.5 & -.5 \\
\hline Lumber and products & 24 & .1 & .3 & 2.4 & 2.1 & 2.8 & -.5 & -.8 & 1.6 & -1.2 & 4 \\
\hline Furniture and fixtures & 25 & .5 & 1.3 & 1.4 & 1.3 & 2.3 & -.5 & -.6 & -.6 & -.4 & -.1 \\
\hline Stone, clay, and glass products & 32 & .1 & .1 & .9 & 1.2 & 2.2 & -.6 & -.1 & .0 & -.5 & -.5 \\
\hline Primary metals & 33 & -1.1 & -.1 & 1.4 & 1.8 & 3.3 & .1 & .2 & -.5 & -.3 & .2 \\
\hline Iron and steel & 331,2 & -2.3 & -1.0 & 2.8 & 1.9 & 4.5 & .0 & .0 & .0 & .0 & .9 \\
\hline Raw steel & $331 \mathrm{pt}$ & -3.0 & -4.2 & .9 & 3.1 & 1.1 & .0 & .0 & .0 & .0 & -2.8 \\
\hline Nonferrous . & $333-6,9$ & .5 & .9 & -.3 & 1.6 & 1.8 & .2 & .4 & -1.0 & -.7 & -.6 \\
\hline Fabricated metal products & 34 & -.1 & 1.5 & 1.5 & 2.7 & 2.9 & -.4 & .4 & -.4 & .5 & .9 \\
\hline Industrial machinery and equipment & 35 & 3.8 & 4.7 & 6.3 & 9.0 & 11.4 & -.3 & -1.1 & -2.4 & -2.4 & -1.1 \\
\hline Computer and office equipment .. & 357 & 14.4 & 19.0 & 22.8 & 29.0 & 36.1 & .4 & .4 & -2.2 & 2.2 & 6.8 \\
\hline Electrical machinery ...... & 36 & 6.5 & 8.1 & 11.7 & 16.6 & 16.5 & .1 & 8 & 2.0 & 1.8 & .9 \\
\hline $\begin{array}{c}\text { Semiconductors and related } \\
\text { components } \ldots \ldots \ldots \ldots\end{array}$ & $3672-9$ & 15.9 & 20.6 & 27.3 & 35.1 & 29.7 & 1.8 & 8.0 & 9.0 & 10.0 & 4.2 \\
\hline Transportation equipment .. & 37 & 1.4 & .7 & 3.0 & 2.8 & 1.3 & -.6 & -1.3 & -.4 & .7 & -.3 \\
\hline Motor vehicles and parts & 371 & 3.2 & 2.9 & 7.5 & 7.2 & 3.4 & -.5 & -1.6 & 9 & 1.6 & -.6 \\
\hline Autos and light trucks & $371 \mathrm{pt}$ & .8 & .0 & 5.5 & 5.9 & 1.8 & -1.6 & -2.7 & -.3 & 2.7 & .0 \\
\hline Aerospace and miscellaneous & $372-6,9$ & .1 & -1.9 & -2.1 & -2.5 & -1.5 & -.2 & -1.1 & -1.8 & -.3 & .2 \\
\hline Instruments $\ldots \ldots \ldots \ldots \ldots$ & 38 & 1.1 & .5 & .2 & .0 & .0 & -.1 & -.4 & -.8 & -.9 & -1.0 \\
\hline Miscellaneous $\ldots \ldots \ldots \ldots \ldots$ & 39 & 1.5 & 1.5 & 1.4 & 1.4 & 1.4 & -3.4 & -2.3 & -2.4 & -2.5 & -2.5 \\
\hline Nondurable & & 2.2 & 1.4 & 1.8 & 1.6 & 1.7 & -.1 & -.4 & -.3 & -.3 & .1 \\
\hline Foods ... & 20 & 2.6 & 1.8 & 2.0 & 2.1 & 1.9 & .4 & -.2 & .0 & .4 & .3 \\
\hline Textile mill products & 22 & 1.7 & 2.5 & 3.5 & 4.1 & 2.4 & -.8 & -.8 & .4 & .4 & .6 \\
\hline Apparel products .... & 23 & .2 & .5 & .4 & 2.9 & 1.3 & -1.9 & -2.1 & -.6 & .8 & .8 \\
\hline Paper and products . & 26 & 1.8 & 2.3 & 1.5 & 1.9 & 1.6 & -.5 & .1 & -.6 & -1.3 & -1.2 \\
\hline Printing and publishing & 27 & .6 & -.8 & -.1 & -.2 & -.5 & -.3 & .0 & -1.7 & -.2 & .0 \\
\hline Chemicals and products & 28 & 3.8 & 2.2 & 3.0 & 2.0 & 3.5 & -.1 & -.4 & .7 & -.4 & .9 \\
\hline Petroleum products & 29 & -1.5 & -.6 & 1.9 & -.2 & .3 & -.3 & .0 & 1.6 & -.8 & -.5 \\
\hline Rubber and plastics products & 30 & 3.8 & 3.3 & 4.3 & 2.3 & 1.6 & -.4 & -.9 & -.4 & -1.2 & -1.5 \\
\hline Leather and products ....... & 31 & -2.6 & -2.1 & -1.7 & -1.9 & -1.4 & .1 & .1 & .8 & .9 & 1.0 \\
\hline Mining & & -1.2 & -.6 & .7 & -.4 & -.4 & .0 & .4 & .8 & -.4 & -.2 \\
\hline Metal mining & 10 & 2.5 & 1.8 & -1.5 & .9 & 1.2 & .0 & .1 & -1.2 & -.1 & .2 \\
\hline Coal mining & 12 & -.3 & 1.4 & 4.3 & -.9 & .8 & -1.2 & .3 & 3.2 & -2.0 & -.2 \\
\hline Oil and gas extraction & 13 & -1.8 & -1.6 & -.2 & -8 & -1.1 & .3 & .3 & .4 & .0 & -.2 \\
\hline Stone and earth minerals ... & 14 & .0 & 1.9 & 1.0 & 1.9 & 1.8 & -.5 & 1.0 & -.5 & -1.1 & -.7 \\
\hline Utilities & & 1.4 & .8 & 1.2 & 1.8 & 2.1 & .3 & .2 & .8 & .8 & .7 \\
\hline Electric ............ & $491,3 \mathrm{pt}$ & 1.5 & 1.4 & 1.0 & 2.2 & 2.6 & .0 & .7 & .6 & 1.1 & 1.0 \\
\hline Gas $\ldots \ldots \ldots \ldots \ldots \ldots \ldots$. & $492,3 \mathrm{pt}$ & .0 & .2 & .4 & .5 & .7 & .0 & .0 & -.1 & -.2 & -.3 \\
\hline Aggregate, excluding computer & & 17 & 15 & 25 & 28 & 30 & -2 & -3 & -1 & $-?$ & -1 \\
\hline 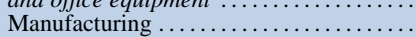 & $\cdots$ & 1.9 & 1.7 & 2.7 & $\begin{array}{l}2.0 \\
3.1\end{array}$ & 3.3 & -.3 & -.4 & -.1 & -.3 & -.1 \\
\hline
\end{tabular}

NotE. See notes to table A.4. Growth rates are calculated as the percentage pt Part of classification. change in the seasonally adjusted index from the fourth quarter of the previous year to the fourth quarter of the year specified. 
A.9. Value added and annual proportions in industrial production, by industry groups, 1994-96

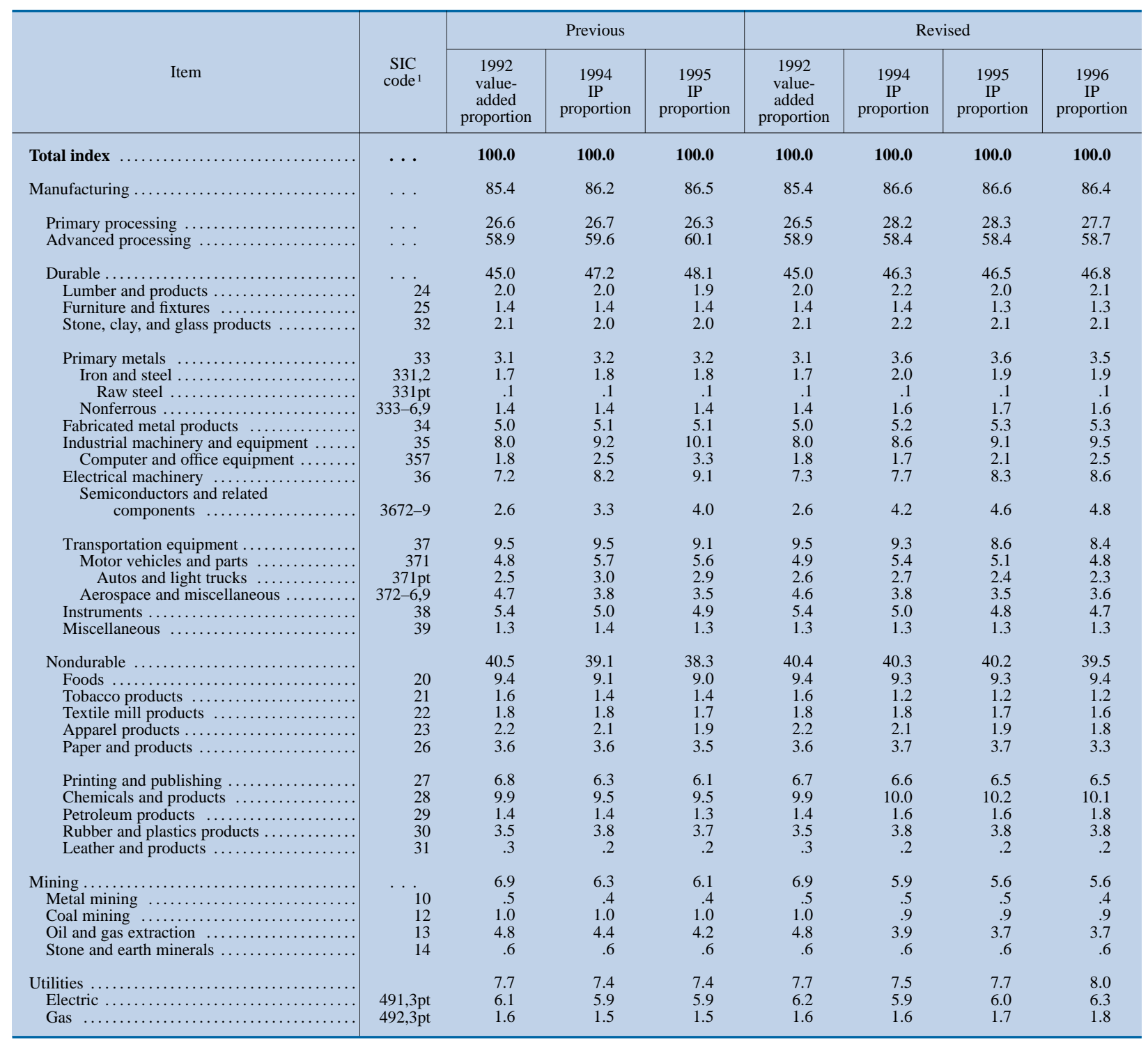

NotE. The IP proportion data are estimates of the industries' relative contributions to overall IP growth in the following year. For example, a 1 percent increase in durable goods manufacturing in 1997 would account for a 0.468 per-

1. Standard industrial classification; see table A.4, note 1 . cent increase in total IP.

\section{APPENDIX B: REVISION OF ELECTRIC POWER DATA}

The Federal Reserve's monthly indexes of industrial electric power use, which begin in 1972, have been revised. ${ }^{12}$ The indexes are now expressed as percentages of electric power use in 1992; the previous

12. The electric power indexes appear in table 9 of the Federal Reserve's monthly statistical release G.17, "Industrial Production and Capacity Utilization." comparison base year was 1987. The revisions of the electric power series stem from three sources: more complete reports from utilities and some changes in the Federal Reserve's utility reporting panel for recent years; more accurate staff estimates of the increase in the electricity generated by individual manufacturing and mining firms for their operations (cogeneration) that took place during the last half of the 1980s; and adjustments of the detailed series on purchased power consumption to annual benchmarks derived from data published in the Annual Survey of 
Manufactures (ASM) from 1972 to 1993. Compared with the previously published data, the revised index of total electric power use in manufacturing and mining shows somewhat stronger growth since 1989 and a slightly greater decline from 1979 to 1982 ; the overall pattern, however, is quite similar to previous results (chart B.1). The revised cogeneration component grows noticeably faster (chart B.2).

Since 1971 the electric power data have been used regularly to estimate key components of the monthly industrial production index. Currently, forty-one individual monthly production series are derived from electric power data, and these series represent 28 percent of the IP index in terms of its 1994 value-added proportions (table B.1). Electricity is an integral input to industrial production processes, with such diverse uses as powering industrial machinery and materials conversion processes to controlling lighting and climate. For these forty-one series, changes in electric power use are generally closely linked to output changes, a linkage that is primarily a reflection of the variation in machine operation rates or materials consumption that accompanies short-run adjustments in production. In the current revision of industrial production, the forty-one production series incorporate the revised electricity data from January 1992 onward.

The electric power data are also used to develop productivity extrapolations after 1994 for production series based on production-worker hours. In the monthly estimation process for the index of production, electric power data continue to be used to review output estimates made with physical product and production-worker-hour data. Thus, the use of electric power series goes beyond the direct monthly estimation of the forty-one series.

\section{B.1. Revised and earlier industrial electric power use,} 1972-96

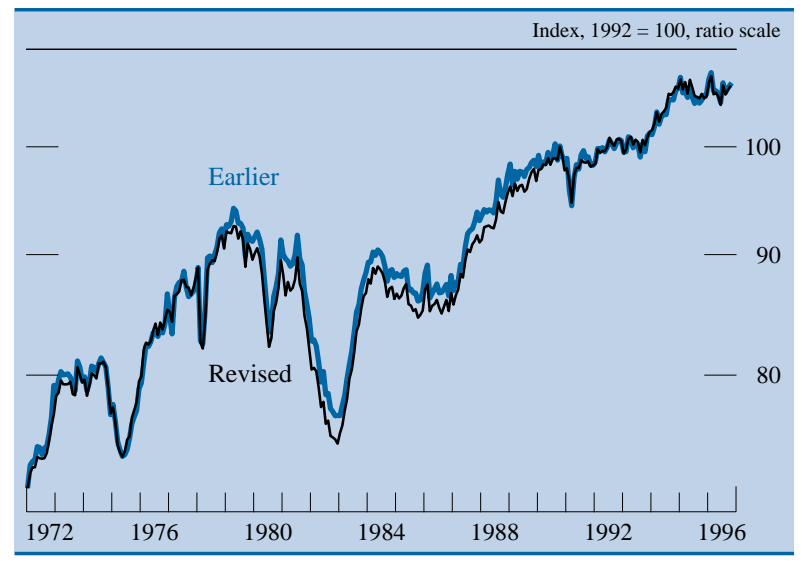

Note. Seasonally adjusted monthly data through November 1996.

\section{Description of Data Collected}

The respondents to the Federal Reserve's Monthly Survey of Industrial Electricity Use report to the Reserve Bank in their Federal Reserve District. The survey consists of two voluntary reports: one for electric utility companies and one for manufacturing and mining firms that are cogenerators. The utilities report their data in thousands of kilowatt-hours of electric power sold to manufacturing and mining establishments classified according to their SIC for 1987.13 Each utility reporter provides, on average, sales data for 120 three-digit SIC industry groups. Each cogenerator reports power used according to the SIC grouping for its own plant.

Currently, 175 utilities and 186 cogenerating companies voluntarily participate in the monthly electric power survey; the response rate for the combined panel is about 95 percent. A comparison of the kilowatt-hour sales reported by utilities to the Federal Reserve with establishment reports in the 1994 ASM indicates that the Board survey captured about 75 percent of the total sales by electric utilities to manufacturing establishments. Seventy-one new cogenerators joined the FRB reporting panel in 1992, raising the sample coverage from about 30 percent of cogener-

13. The reports are based on monthly meter readings, or billings, and may not uniformly represent electric power use. However, a new data collection procedure implemented in 1990 has allowed easier detection of instances of billing for two months or of delayed reporting. The possibility of a systematic irregular relation of billing periods (once corrected) to calendar months is generally rejected by the data; a statistical analysis comparing electric power data with productionworker-hour data for seventy different SIC codes showed the reports to be significantly more closely related for the same months than at any lag.

\section{B.2. Revised and earlier electric power cogeneration, 1982-96}

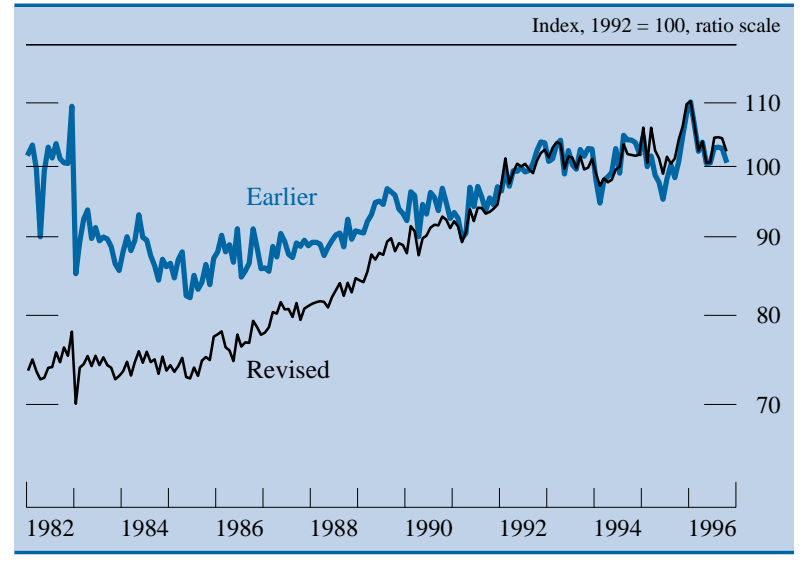

Note. Seasonally adjusted monthly data through November 1996. 
B.1. Industrial production series based on electric power components as a proportion of total industrial production, 1994

Percent

\begin{tabular}{|c|c|}
\hline Series & $\begin{array}{l}\text { Proportion of } \\
\text { IP index in } 1994\end{array}$ \\
\hline Total & 28.31 \\
\hline Job printing & 2.98 \\
\hline Drugs and medicines . & 2.80 \\
\hline Office and computing equipment & 2.09 \\
\hline Medical instruments ........... & 1.57 \\
\hline Soap and toiletries . & 1.51 \\
\hline Canned and frozen food & 1.29 \\
\hline Metalworking machinery & 1.09 \\
\hline Bakery products ......... & 1.01 \\
\hline Miscellaneous machinery & .99 \\
\hline Metal stampings ......... & .98 \\
\hline Soft drinks ..... & .88 \\
\hline Miscellaneous foods, n.e.c. & .81 \\
\hline General industrial equipment & .75 \\
\hline Electrical industrial apparatus & .68 \\
\hline Lighting and wiring products & .68 \\
\hline Office furniture, fixtures, and miscellaneous & .65 \\
\hline Household furniture $\ldots \ldots \ldots \ldots \ldots \ldots \ldots$ & .64 \\
\hline Miscellaneous rubber products & .60 \\
\hline Concrete and plaster products .. & .60 \\
\hline Miscellaneous chemical products & .59 \\
\hline Hardware and tools .... & .48 \\
\hline Computer parts & .45 \\
\hline Iron and steel foundries & .44 \\
\hline Miscellaneous stone and earth manufacturers & .39 \\
\hline Metal services, wire products .............. & .37 \\
\hline Knit garments . & .36 \\
\hline Children's and miscellaneous garments . & .33 \\
\hline Agricultural chemicals, n.e.c. .......... & .32 \\
\hline Bolts, fasteners ........... & .32 \\
\hline Electrical distribution equipment & .30 \\
\hline Glass products .......... & .24 \\
\hline Paving and roofing materials & .19 \\
\hline Feeds $\ldots \ldots \ldots \ldots \ldots \ldots \ldots$ & .18 \\
\hline Wood products, n.e.c. .... & .17 \\
\hline Miscellaneous glassware ..... & .14 \\
\hline Miscellaneous primary metals & .13 \\
\hline Plumbing fixtures ............ & .11 \\
\hline Wood containers .. & .07 \\
\hline Leather and belting & .05 \\
\hline Miscellaneous metal ores & .03 \\
\hline Consumer glassware . & .03 \\
\hline
\end{tabular}

n.e.c. Not elsewhere classified.

ated power to about 50 percent, judging from ASM data. Altogether, the panel of utilities and cogenerators accounts for about 73 percent of total industrial use of electric power in the United States.

\section{Aspects of the Revision of Electric Power Data}

The revised data incorporate more complete reports that have been received from respondents since the 1995 annual update. The new figures incorporate a more accurate classification of customer SIC codes by the utility respondents and also some changes in the reporting panel back to 1989. Although the effects of these changes are generally small relative to U.S. totals, the classification changes have improved the recent figures by detailed industry classification.
The electric power database has been revised back to 1982 to reflect the expansion of the cogenerator panel. Data provided by new participants in the cogenerator panel were incorporated in the revision of the electric power indexes in July 1994, which covered the period back to December 1991. The new participants typically began cogenerating operations after 1982 and contributed to the increase in cogeneration that took place in the last half of the 1980s. Passage of the 1978 Public Utilities Regulatory Policies Act stimulated much of this increase. In this revision, the staff estimated the likely effect of these new reporters on cogeneration at the three-digit SIC level for the years back to 1982 consistent with aggregate data on cogeneration from the ASM. New individual cogeneration series were prorated back linearly to zero in January 1982, unless we had specific information to indicate otherwise.

This revision introduced adjustments to annual benchmarks for the monthly electric purchased power series derived from ASM data at the three-digit SIC level. The purpose of these adjustments was to improve the accuracy of the Federal Reserve's historical data by detailed industry classification. The overall index has always captured total industrial power use quite well, judging from the ASM data, but discrepancies at the three-digit level were sizable. ${ }^{14}$

The benchmark adjustments to each Federal Reserve series involved the following steps: (1) The annual ASM series on purchased electric power was indexed and then converted to a monthly series by interpolating linearly between the annual index values. (2) The ratio of the ASM-Census monthly index to the Federal Reserve monthly index was calculated. (3) A centered, three-year average of the ratio was determined, with the weights for computing the threeyear average tapered for twelve months at the beginning and end of the three-year period. (4) The smoothed monthly ratios were multiplied by the original Federal Reserve monthly index values to obtain the final monthly index. This method of adjustment to benchmarks preserves the higher-frequency, month-to-month changes in the Federal Reserve series while ensuring that the longer-run trends in the ASM data are reproduced.

14. Comparisons with Department of Energy (DOE) data on industrial sales of electricity by utilities are not useful because the industrial classification used by DOE relates partly to size of establishment; it includes large commercial and irrigation customers in the industrial category, while frequently classifying small industrial customers as commercial. 


\section{Results of the Revision}

The revisions for major series are generally small (table B.2). The largest users of electric power are the chemicals, primary metals, and paper industries, followed by producers of food products, petroleum products, transportation equipment, and rubber and plastics products. Within chemicals, the inorganic chemical and plastics materials industries are the major consumers, and within primary metals, basic steel and primary aluminum processing absorb large amounts of electric power. Among these major industrial groups, the largest revisions since 1989 occur in petroleum refining.

Two-digit SIC groups of series were seasonally adjusted using a multivariate procedure that, in comparison with standard methods, yields seasonal factors that contain less noise and tend to be more stable as new data are received. ${ }^{15}$ The standard deviation of the monthly growth rates for total electric power use is about 1.2 percentage points from 1973 to the present; it is about 0.9 percentage point over that period if recessions are excluded. The measurement precision of the growth rates is largely determined by the utility sample, which represents about 90 percent of total combined sample coverage (utilities plus cogenerators). A statistical analysis of the utility data suggests that the standard deviation of the measurement error of growth rates for total power use is 0.5 percentage point. For cogenerators, the standard deviation of the errors for sample growth rates is larger, 1.9 percentage points, but has been reduced from 3.0 percentage points, which was the standard deviation before the 1992 expansion of the reporting panel. These estimates of standard errors decline as the period of the growth rate lengthens.

15. See Eric J. Bartelsman and William P. Cleveland, "Joint Seasonal Adjustment of Economic Time Series," Finance and Economics Discussion Series No. 93-28 (Board of Governors of the Federal Reserve System, August 1993).

\section{B.2. Revised growth rates of electric power use, 1973-96}

\begin{tabular}{|c|c|c|c|c|c|c|c|}
\hline \multirow[t]{2}{*}{ Series } & \multirow{2}{*}{$\begin{array}{c}\text { Billions of } \\
\text { kilowatt hours } \\
\text { in } 1992^{1}\end{array}$} & \multicolumn{3}{|c|}{$\begin{array}{l}\text { Revised growth rates } \\
\text { (percent) }\end{array}$} & \multicolumn{3}{|c|}{$\begin{array}{l}\text { Difference between revised } \\
\text { and earlier growth rates } \\
\text { (percentage points) }\end{array}$} \\
\hline & & $1973-79$ & 1979-89 & 1989-96 & 1973-79 & $1979-89$ & $1989-96$ \\
\hline Total index & 934.1 & 2.4 & .5 & 1.3 & -.1 & .0 & .1 \\
\hline Total utilities & 835.3 & 2.6 & .5 & 1.2 & -.2 & -.1 & .2 \\
\hline Total cogeneration & 98.8 & -1.6 & 1.0 & 2.4 & 2.8 & 1.7 & 1.1 \\
\hline Total manufacturing & 854.0 & 2.2 & 6 & 1.3 & -.1 & .0 & .2 \\
\hline Durable manufacturing & 365.8 & 1.9 & .1 & .6 & .1 & .0 & .1 \\
\hline Nondurable anufacturing & 488.3 & 2.5 & 1.0 & 2.0 & -.2 & -.1 & .2 \\
\hline Mining.$\ldots \ldots \ldots \ldots \ldots \ldots$ & 80.1 & 5.6 & .4 & 1.0 & -.2 & .2 & .0 \\
\hline Two-digit industries & & & & & & & \\
\hline Chemicals and products & 171.7 & 2.4 & -.5 & 1.5 & -.5 & -.5 & .0 \\
\hline Primary metals ....... & 150.9 & 1.9 & -1.8 & -.6 & .3 & .1 & .0 \\
\hline Paper and products & 113.3 & 3.2 & 2.7 & 1.6 & .6 & .5 & -.1 \\
\hline Food and kindred products & 58.8 & 2.7 & 2.4 & 2.6 & -.3 & .0 & .1 \\
\hline Petroleum products ....... & 47.0 & 3.5 & 1.9 & 2.9 & .1 & 1.3 & 1.5 \\
\hline Transportation equipment & 39.6 & .4 & 2.0 & .6 & .1 & .3 & .4 \\
\hline Rubber and plastic products & 38.0 & 4.8 & 3.0 & 4.3 & .0 & -.5 & .0 \\
\hline Oil and gas extraction ....... & 36.0 & 3.1 & .5 & .2 & .2 & -.1 & .2 \\
\hline Stone, clay, and glass products & 33.8 & 2.7 & .0 & 1.0 & .0 & .1 & .0 \\
\hline Industrial machinery and equipment & 33.2 & 3.1 & 1.8 & .6 & .2 & -.1 & -.2 \\
\hline Electrical machinery........... & 33.0 & 1.4 & 1.6 & 2.2 & 1 & -.3 & .8 \\
\hline Textile mill products & 31.5 & .4 & 1.0 & 1.4 & .0 & .0 & .1 \\
\hline Fabricated metal products & 31.4 & 2.1 & 1.4 & 1.4 & -.5 & -.4 & .2 \\
\hline Lumber and products .... & 19.8 & 2.3 & 2.0 & 2.5 & -2.2 & -1.2 & -.1 \\
\hline Metal mining..$\ldots \ldots \ldots$ & 18.6 & 9.3 & .1 & 2.9 & -.3 & 1.0 & -.5 \\
\hline Printing and publishing & 17.3 & 2.2 & 4.9 & 2.6 & -.7 & -.2 & -.1 \\
\hline Instruments $\ldots \ldots \ldots \ldots$ & 13.7 & 2.3 & 4.7 & .8 & .0 & .0 & 1.3 \\
\hline Stone and earth minerals ... & 12.8 & 4.5 & -.1 & 1.4 & -.7 & .2 & -.4 \\
\hline Coal mining $\ldots \ldots \ldots \ldots \ldots$ & 12.7 & 7.6 & 1.2 & -.2 & .1 & -.3 & .3 \\
\hline Apparel products...$\ldots \ldots$ & 8.2 & -1.9 & .7 & .0 & -3.1 & -1.7 & -.5 \\
\hline Furniture and fixtures ...... & 6.0 & 1.0 & 3.3 & 1.8 & -1.0 & .2 & -.4 \\
\hline Miscellaneous manufactures & 4.5 & 2.3 & 1.0 & 4.1 & -.6 & -.1 & -.6 \\
\hline Tobacco products ......... & 1.5 & 2.5 & 1.9 & .5 & 2.3 & 2.4 & -3.0 \\
\hline Leather and products ..... & 1.0 & -2.1 & -2.0 & -2.5 & -1.0 & -3.0 & -1.5 \\
\hline
\end{tabular}

Note. Growth rates are calculated as the annual percentage change from the first year to the last year indicated. The 1996 estimate is the average through 1. Sold in 1992 to each category as reported by the Bureau of the Census. November. 